\title{
Volcanism and Volcanogenic Submarine Sedimentation in the Paleogene Foreland Basins of the Alps: Reassessing the Source-to-Sink Systems with an Actualist View
}

\author{
Andrea Di Capua ${ }^{1, * \mathbb{C}}$, Federica Barilaro ${ }^{2}$ and Gianluca Groppelli ${ }^{1}[$ \\ 1 Institute of Environmental Geology and Geoengineering, Italian National Research Council (CNR), Via Mario \\ Bianco 9, 20131 Milano, Italy; gianluca.groppelli@cnr.it \\ 2 Department of Theoretical and Applied Sciences, Previously at University of Insubria, 21100 Varese, Italy; \\ federicabarilaro@pec.it \\ * Correspondence: andrea.dicapua@igag.cnr.it
}

check for updates

Citation: Di Capua, A.; Barilaro, F.; Groppelli, G. Volcanism and Volcanogenic Submarine Sedimentation in the Paleogene Foreland Basins of the Alps: Reassessing the Source-to-Sink Systems with an Actualist View. Geosciences 2021, 11, 23. https://doi.org/ 10.3390/geosciences 11010023

Received: 11 December 2020 Accepted: 30 December 2020 Published: 4 January 2021

Publisher's Note: MDPI stays neutral with regard to jurisdictional clai$\mathrm{ms}$ in published maps and institutional affiliations.

Copyright: (C) 2021 by the authors. Licensee MDPI, Basel, Switzerland. This article is an open access article distributed under the terms and conditions of the Creative Commons Attribution (CC BY) license (https:// creativecommons.org/licenses/by/ $4.0 /)$.

\begin{abstract}
This work critically reviews the Eocene-Oligocene source-to-sink systems accumulating volcanogenic sequences in the basins around the Alps. Through the years, these volcanogenic sequences have been correlated to the plutonic bodies along the Periadriatic Fault System, the main tectonic lineament running from West to East within the axis of the belt. Starting from the large amounts of data present in literature, for the first time we present an integrated 4D model on the evolution of the sediment pathways that once connected the magmatic sources to the basins. The magmatic systems started to develop during the Eocene in the Alps, supplying detritus to the Adriatic Foredeep. The progradation of volcanogenic sequences in the Northern Alpine Foreland Basin is subsequent and probably was favoured by the migration of the magmatic systems to the North and to the West. At around $30 \mathrm{Ma}$, the Northern Apennine Foredeep also was fed by large volcanogenic inputs, but the palinspastic reconstruction of the Adriatic Foredeep, together with stratigraphic and petrographic data, allows us to safely exclude the Alps as volcanogenic sources. Beyond the regional case, this review underlines the importance of a solid stratigraphic approach in the reconstruction of the source-to-sink system evolution of any basin.
\end{abstract}

Keywords: periadriatic magmatism; northern alpine foreland basin; Northern Apennines; Taveyanne sandstones; Val d'Aveto-Petrignacola formation; SE France

\section{Introduction}

During the Eocene-Oligocene boundary, different magmatic systems developed in the Alpine belt, as testified by the large amounts of plutonic bodies and volcanic/volcanogenic sequences within and surrounding the main core of the belt (Figure 1). The deepest roots of such systems are included in the Periadriatic Magmatism (PM) plutons, whereas, on the surface, dykes crosscutting metamorphic and sedimentary units in the Southern Alps, and volcanic sequences of the Venetian Volcanic Province (VVP), the Biella Volcanic Suite (BVS), the Cerano-Mortara-Garlasco (CMG) volcanic centre and the Provence volcanoes (PV) represent the coeval surficial volcanic manifestations [1-4]. In addition, thick volcanogenic deposits in the foreland basins border the belt [5-8]. Within these latter sequences, some authors also include the volcanogenic turbidite system of the Val d'Aveto-Petrignacola Formation (APF) in the Northern Apennine Foredeep [9].

This work reviews the large amounts of lithostratigraphic, biostratigraphic, sedimentological, petrographic, petrological, geochronological and tectonic data available from literature on these magmatic products, describing them from the plutonic and subvolcanic bodies, to the volcanic and volcanogenic sequences. In addition, it includes new WDS geochemical data on two different volcanogenic formations, one in the Adriatic Foredeep and the other in the Northern Apennine Foredeep. 


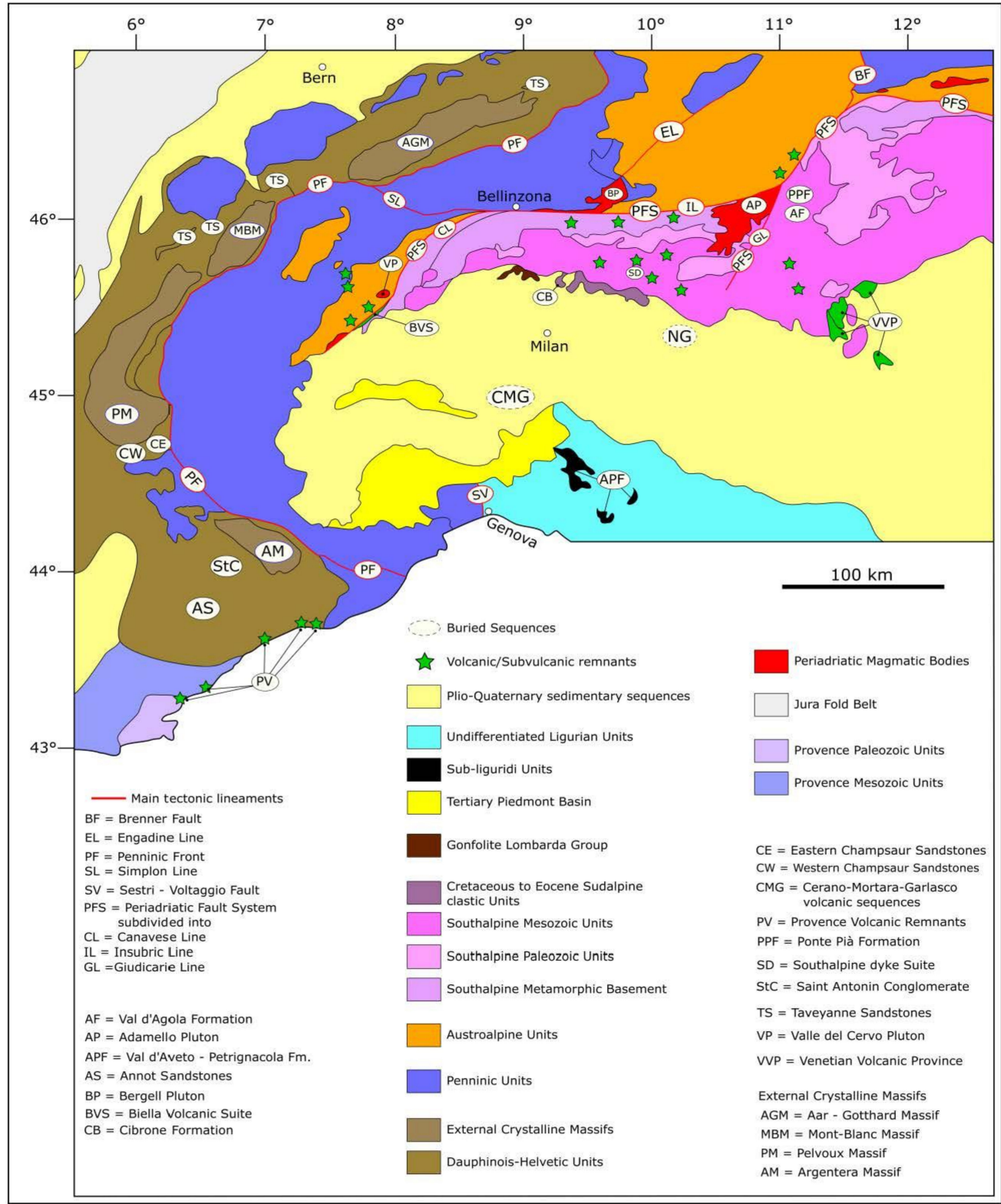

Figure 1. Geological map of the Alps, modified from [10-12].

The result is a new 4D stratigraphic model that better constrains the source-to-sink systems actively connecting the Alpine belt to the surrounding sedimentary systems across the Eocene-Oligocene time. The first magmatic systems were in the Southern Alps, in the southern Adamello area and the VVP area, and favoured the accumulation of volcanogenic sequences in all the Adriatic Foredeep. Then, magmatic sources progressively migrated to the north and to the west, leaving the Adriatic Foredeep starved but supplying large amounts of detritus to the Northern Alpine Foreland Basin (NAFB). At around $30 \mathrm{Ma}$, the volcanogenic detritus also reached the Northern Apennine Foredeep from a source area different from the Alps.

Beyond the regional case, this work strongly highlights how solid stratigraphic constraints are fundamental in the reconstruction of the evolution of any source-to-sink system.

\section{The Source: Alpine Belt and Periadriatic Magmatism}

\subsection{The Alpine Belt}

During the Eocene and the Lower Oligocene, only part of the modern Alpine belt was already exhumated and exposed to the surface. This part includes the central southern 
Alps, bordered to the west by the Canavese line (CL), to the north by the Insubric line (IL) and to the east by the Giudicarie line (GL) $[4,13]$, the Sesia Lanzo block (NW of the CL (Figure 1)), although not rotated as currently [14,15], and the Austroalpine terrains in the Eastern part of Switzerland [12,16]. On the contrary, most of the Pennine nappes, including the Lepontine dome actually interposed between the Bergell pluton and the NAFB, were still involved in subduction [17]. In particular, it has been demonstrated that in the central part of the Alps, the Pennine nappes have been interposed between the Austroalpine domains and the Helvetic domain only at the end of the Late Oligocene-Early Miocene [16-19].

\subsection{Plutonism}

The most known expression of the Cenozoic magmatic activity in the Alps is represented by the large plutons aligned or near the PFS (Figures 1 and 2). Their emplacement was, at the beginning, considered as the crustal expression of a deep geodynamic mechanism known as slab break-off [20], and magmas ascended along the PFS [21]. In 2015, [22] postulated that the magmatic event was triggered by the retreat of the European slab and the progressive shift of the subduction partial melting zone from SE (Venetian area) to the orogeny before the slab break-off, on the base of geochemical and geochronological data on dykes of the Southern Alps. Currently, the work of [23] (and ref. therein), based on the tomographic images showing the unbroken European slab below the Adriatic plate, indicates that slab steepening, and not slab break-off, triggered the magma generation. Among all, three plutons are mainly considered in the proposed reconstruction: the Adamello pluton (50.0-30.5 Ma, according to [24-26]); the Bergell pluton (33-29 Ma, according to [27] and ref. therein), and the Biella pluton (30.5-30.1 Ma, according to [28]). In general, all plutons show a calc-alkaline to shoshonitic/ultrapotassic affinity, associated to a westward increasing in K, with the only exception of the oldest (and southernmost) suites of the Adamello batolith, generated from ultramafic to mafic mantle melts [29].

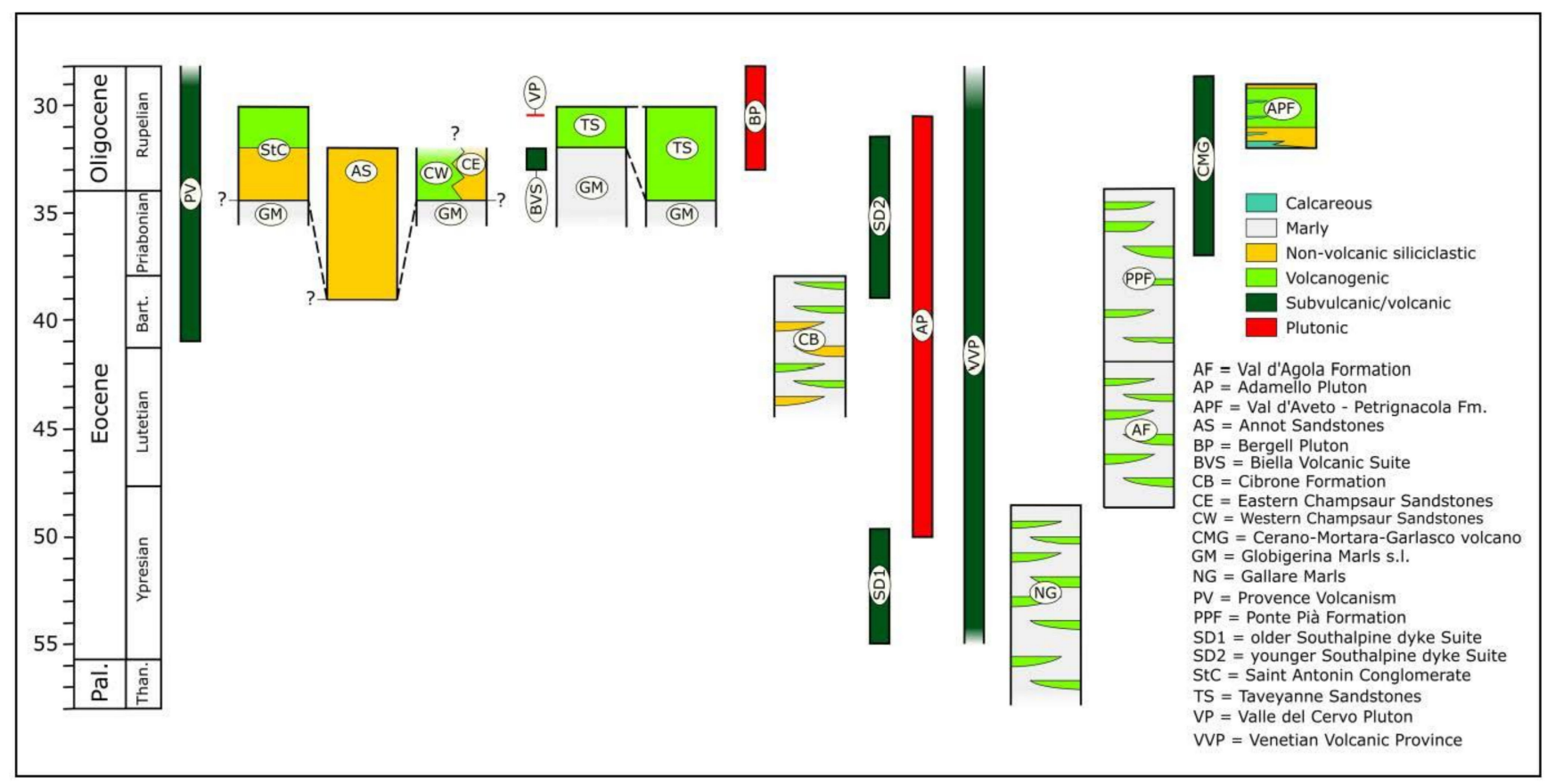

Figure 2. Magmatic manifestations and general stratigraphy of the sedimentary sequences included in the Northern Alpine Foreland Basin, Adriatic Foredeep and Northern Apennine Foredeep. Data from [1,2,5,9,11,26,30-37]. Shade sides mean that no temporal constraints are available. 


\subsection{Volcanoes and Volcanogenic Sequences}

The surface expressions of the PM are scattered and/or badly exposed, and include dykes and subintrusive bodies, pyroclastic, hyaloclastite and volcanogenic deposits, as well as a volcanic edifice buried below the Plio-Holocene sediments of the Po Plain (the Mortara Volcano) (Figures 1 and 2). In general, dyke compositions strictly follow the geochemical compositions of the related plutons. Thus, they show a calc-alkaline to shoshonitic/ultrapotassic affinity, with a more heterogenous petrographic association in the Western Alps [38,39]. Only dykes magmatically related to the oldest suites of the Adamello show a tholeiitic to calc-alkaline association, which reaches high-k calc-alkaline affinity in the youngest dykes [22].

The Biella Volcanic Suite (BVS) includes volcanogenic deposits subaerially accumulated from 32.89 to $32.44 \mathrm{Ma}$ on top of an Oligocene regolith, and [3,40,41] describe the suite as composed of dykes and remnants of explosive activity that accumulated thick volcanic breccia and tuff deposits. According to [14,15], after their emplacement, the BVS was tilted to SE with an angle of $60^{\circ}$.

Pluridecametric subintrusive bodies, feeding dykes and sills, crop out in the southernmost offshoots of the Alps (Figure 1). As described by [42] (and ref. therein), these bodies are characterized by porphyritic textures embedding plagioclase and hornblende as phenocrystals, and have a geochemical composition that ranges among andesite, trachyandesite and basalt. On the basis of geochronological ages (K/Ar and ${ }^{40} \mathrm{Ar} /{ }^{39} \mathrm{Ar}$ ages), two sets of subintrusive bodies have been recognized, one emplaced from $55.2 \pm 1.4$ to $49.7 \pm 1.3 \mathrm{Ma}$, the second one from $38.9 \pm 1.1 \mathrm{Ma}$ to $31.4 \pm 4.1 \mathrm{Ma}[1,42,43]$. The second sets is mainly basaltic in composition [42]. In the northern part of the Alps, few dykes were described within the Nummulithic Limestones (Priabonan NAFB deposits) [44] and south of the Aar Massif. The latter is inaccessible because it is beneath the Gotthard nappe [45].

Away from the PFS, the VVP includes different NNW-SSE trending eruptive centres that have been grouped in function of their location and products: the first group, active from the middle Paleocene to the Miocene, with ages that decrease from NW to SE, was emplaced in the northwestern part of the province and is characterized by alkaline to subalkaline products (from nephelinites and hawaiites to basalts and basaltic andesites) ([46] and ref. therein). In this group it must be mentioned the so-called Val Lagarina basalt, a volcanic body including effusive submarine manifestations (e.g., pillow basalts, hyaloclastites), dykes, small diatremes, as well as volcaniclastic sandstones (Middle to Late Eocene [47]). The second group, active from the Eocene to Oligocene in the southeastern part of the province, includes subvolcanic bodies, whose composition evolves from alkaline to subalkaline (e.g., trachites, rhyolithes and latites) ([46] and ref. therein).

The CMG volcanic centre was first described by [48]. Located in the southern part of the Po Plain (Figure 1), this centre includes different volcanic eruptive deposits that embrace a timespan from 37 to $28.5 \mathrm{Ma}$ [1]. The oldest and thinner deposits are those recovered in the Garlasco 01 ( $\sim 37 \mathrm{Ma}$ ) and the Cerano 01 ( $\sim 34 \mathrm{Ma})$ wells drilled by E.N.I. The Garlasco 01 well includes a 20-m thick dacite, characterized by oligoclase, K-feldspar, quartz and biotite phenocrystals embedded in a microcrystalline, locally fluidal, groundmass with biotite microliths. Rare amphibole, strongly weathered, are present. This sequence is interbedded in the Middle-Upper Eocene Gallare Marls Formation [1]. The Cerano 01 well includes $55 \mathrm{~m}$-thick volcaniclastic beds interbedded with the Middle-Upper Eocene Gallare Marls, composed of microcrystalline andesitic lava fragments, with phenocrystals of zoned plagioclase, hornblende, very rare pyroxene and accessory minerals, and single minerals of plagioclase and hornblende [1]. The thickest and partially youngest deposits have been recovered in the Mortara 01 well of the E.N.I. Dated at $28.5 \pm 0.1 \mathrm{Ma}$, the volcanic succession in this well reaches ca. $1400 \mathrm{~m}$ in thickness and is mainly composed of porphyritic lavas, with andesitic to dacitic-rhyodacitic composition [1]. The andesitic lavas include plagioclase, clinopyroxene, amphibole and biotite as phenocrystals, whereas the dacite-rhyodacite include plagioclase, biotite and quartz as phenocrystals [49]. 


\section{The Sink: Alpine Peripheral Basins and Their Stratigraphy}

\subsection{The Northern Alpine Foreland Basin (NAFB)}

In the NAFB, thick clastic sequences started to be accumulated at the end of the Eocene, closing the so-called Priabonian Trilogy on top of the (1) Nummulithic Limestones and the (2) Globigerina or Blue Marls [50-52]. Four clastic successions are grouped into four formations, named Annot Sandstones (Grés de Annot), Saint Antonin Conglomerate (Conglomérats de Saint Antonin), Champsaur Sandstones (Grés du Champsaur) and Taveyanne Sandstones (Grés de Taveyannaz) [5-7,51,53] (Figure 2).

The Annot Sandstones (Upper Eocene-Lower Oligocene) are exposed in the SE part of the French Alps and represent a nonvolcanic deep-water turbidite system, fed by detritus sourced from the Sardinia-Corsica margin and the Maures-Esterel Massifs [51].

The Saint Antonin Conglomerate (Upper Eocene to Lower Oligocene) crops out in the French Maritime Alps and consists of three coarsening-upward megasequences, formed of channelized conglomerates and massive sandstones with a total thickness of ca. $950 \mathrm{~m}$ ([5] and ref. therein). The lowermost megasequence has a genetic correlation with the Annot Sandstones and was accumulated in an open marine, outer shelf to upper bathyal environment, whereas the other two members mark the progressive sea level regression and the consequent infill of the basin [5]. Sediments are mainly composed of plutono-metamorphic detritus, with minor amounts of calcareous and sandy material. In addition, between 32 and $29 \mathrm{Ma}$ (biostratigraphic analyses of [54]), volcaniclastic detritus and volcanic breccia deposits of unknown origins have been recognized and dated between $36.1 \pm 2.2$ and $30.8 \pm 2.4$ Ma through the ${ }^{40} \mathrm{~K} /{ }^{39} \mathrm{Ar}$ and ${ }^{40} \mathrm{Ar} /{ }^{39} \mathrm{Ar}$ methods, with a mean age at $33.7 \pm 1.6 \mathrm{Ma}[5,33,55,56]$.

The Champsaur Sandstones were accumulated in the homonymous basin developed SE of the Pelvoux Massif (Haute Alps Department), from the Uppermost Eocene to Lower Oligocene $[7,57]$. However, the large amounts of reworked fossils in the sediments makes the lower boundary uncertain [30]. Several works identify two different sub-basins: Eastern and Western Champsaur sub-basins ([53] and ref. therein). The most studied is the Eastern Champsaur sub-basin, considered a distal offshoot of the above-mentioned Annot basin [53]. In this basin, nonvolcanic siliciclastic sediments coming from $\mathrm{SE}$ were accumulated according to the stratotype of [53] (and ref. therein): a lower package of sandy bodies (ca. $450 \mathrm{~m}$-thick), a middle shale interval (ca. $100 \mathrm{~m}$ thick) and an upper package of sandy bodies (ca. $500 \mathrm{~m}$ thick). Differently, the Western Champsaur sub-basin was fed by a syn-sedimentary volcanic source that led to the deposition of volcaniclastic, often very coarse deposits with andesitit cobbles interbedded by marly layers [7,30]. Volcanogenic detritus holds an ${ }^{40} \mathrm{Ar} /{ }^{39} \mathrm{Ar}$ age of $34.3 \pm 1.0$ and $32.5 \pm 2.2 \mathrm{Ma}[56]$ and its calc-alkaline geochemical signature indicates that the parental volcanism has a heterogenous origin [7]. It is, in fact, enriched in light rare-earth elements relative to heavy rare-earth elements and has a positive $\varepsilon N d(0-4)$ correlated with values of ${ }^{87} \mathrm{Sr} /{ }^{86} \mathrm{Sr}$ ranging from ca. 0.706 to 0.707 , as well as $\mathrm{d}^{18} \mathrm{O}$ values from 38.407 to 38.534 [7]. These geochemical features have been interpreted as typical of magmas derived from a mixed-mantle and minor-continental crust source [7]. This geochemical signature is also comparable to that of the Saint Antonin Conglomerate, as well as to those of the plutonic bodies of the PM [7]. According to [30], the accumulation of the volcanogenic detritus occurred in a proximal turbidite system developed in a rapid-subsiding depocenter, elongated parallel to the fronts of the Alpine belt.

The Taveyanne Sandstones are widely exposed in the Alpine chain from SE France (Haute Savoie Department) to SE Switzerland (Canton of Graubünden) (Figure 1) [6,50]. They consist of volcaniclastic successions intercalated by thin marly beds, arranged in sedimentary architectures ascribed to different deep-water turbidite systems and related subenvironments accumulated from $\sim 34$ in SE Switzerland, 32 in SE France to 29 Ma $[31,58]$. Volcanic pebbles were dated between 32.5 and $30.5 \mathrm{Ma}$ with the ${ }^{40} \mathrm{Ar} /{ }^{39} \mathrm{Ar}$ method $[31,56]$. Detailed petrographic analyses of [6,8], as well as isotopes analyses of [7] on volcanic particles, reveal that the volcanic detritus was mixed with nonvolcanic detritus and both were sourced by syn-sedimentary volcanic edifices located along the PFS, together with the plutono- 
metamorphic terrains of the growing Alpine belt and the calcareous sequences of the Nummulite Limestones (Figure 3). These results have been later confirmed by $\mathrm{U} / \mathrm{Pb}$ and geochemical analyses $\left({ }^{176} \mathrm{Hf} /{ }^{177} \mathrm{Hf}(\mathrm{t})\right.$ and Eu $/ \mathrm{Eu}^{*}$ ratios) on detrital zircons by $[12,37,59]$. In particular, the authors document that few are the magmatic zircons within the formation, characterized by two clustering ages around 41-29 Ma and 34-30 Ma in SE Switzerland and SE France, respectively. In SE Switzerland, the population is further subdivided into sandstone layers with zircon ages ranging from 41 to $32 \mathrm{Ma}$ and a geochemical signature typical of the Adamello magmatic system, and sandstone layers with zircon ages ranging 33-29 Ma and a geochemical signature typical of the Bergell magmatic system. In SE France, magmatic zircons have a geochemical signature typical of the Biella magmatic system [12]. The interposed plutono-metamorphic basement sourced the nonvolcanic zircons [12,37,59]. According to [31], volcanogenic detritus is generally intermediate in composition, also comprising minor amounts of basic and acid terms (Figure 4). The positive relationship existing among bed thickness, bed grain size and content of volcanogenic particles (Figure 5) led to the identification of a volcanic control on the sedimentary system: During syn-eruptive periods, the rapid supply of volcanogenic detritus by the volcanic sources induced the accumulation of thick and coarse volcanogenic beds, whereas during noneruptive periods, the progressive decrease in sediment availability led to the drastic decrease in the accumulation of coarse-grained beds, favouring the accumulation of marly detritus [8]. Furthermore, the presence of volcanic bombs and lapilli [58], as well as bedforms recognized in the French area, seems to indicate that sediments were, in part, directly supplied by subaerially pyroclastic density currents that were disaggregated entering the water and moved downslope as water-supported flows [8].

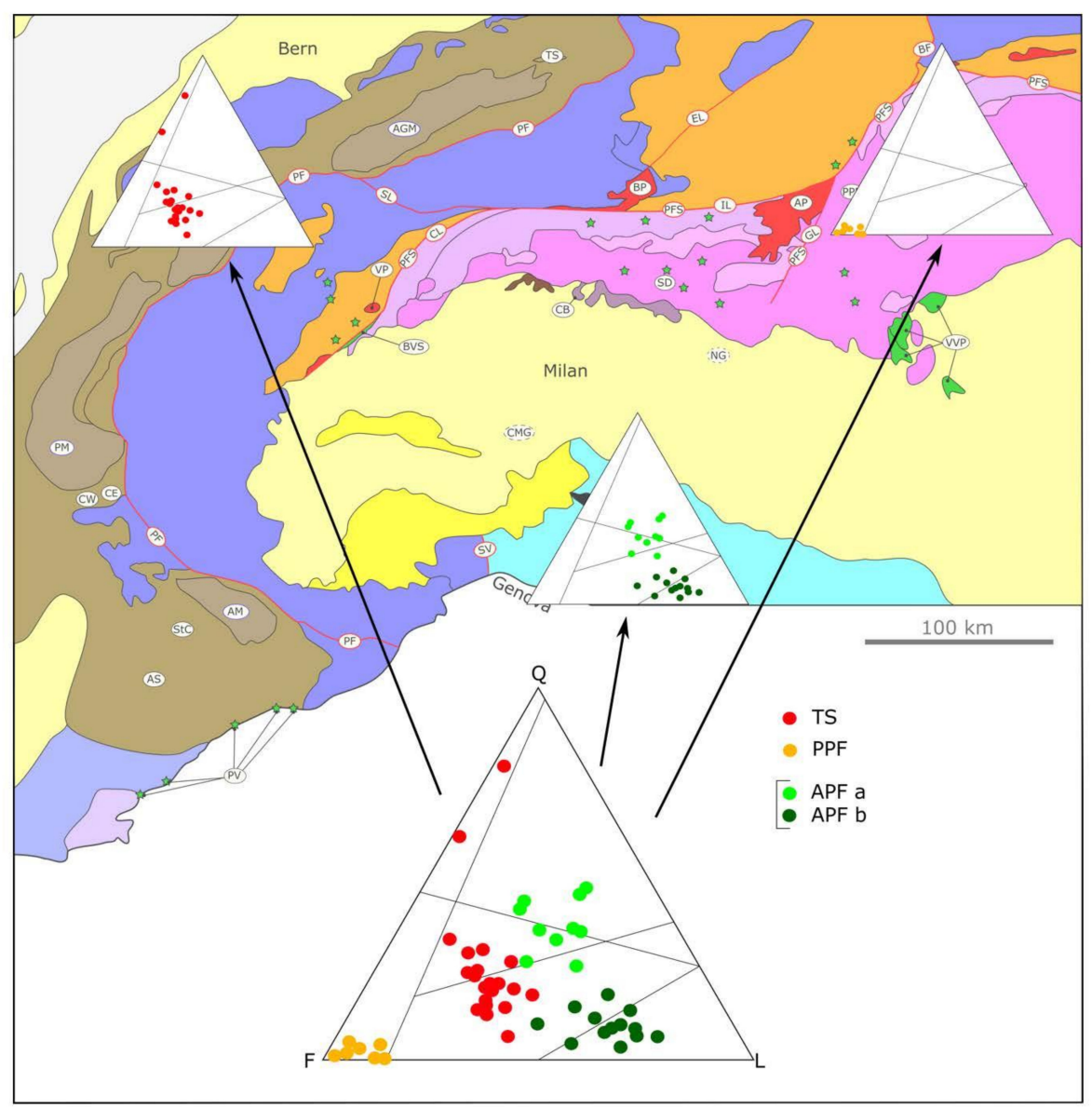

Figure 3. $\mathrm{QFL}_{\text {tot }}$ diagrams. TS = Taveyanne Sandstones [31]; PPF = Ponte Pià Formation [32]; APF = Val d'Aveto-Petrignacola Formation nonvolcanic deposits (a) and volcanogenic deposits (b) [60]. 


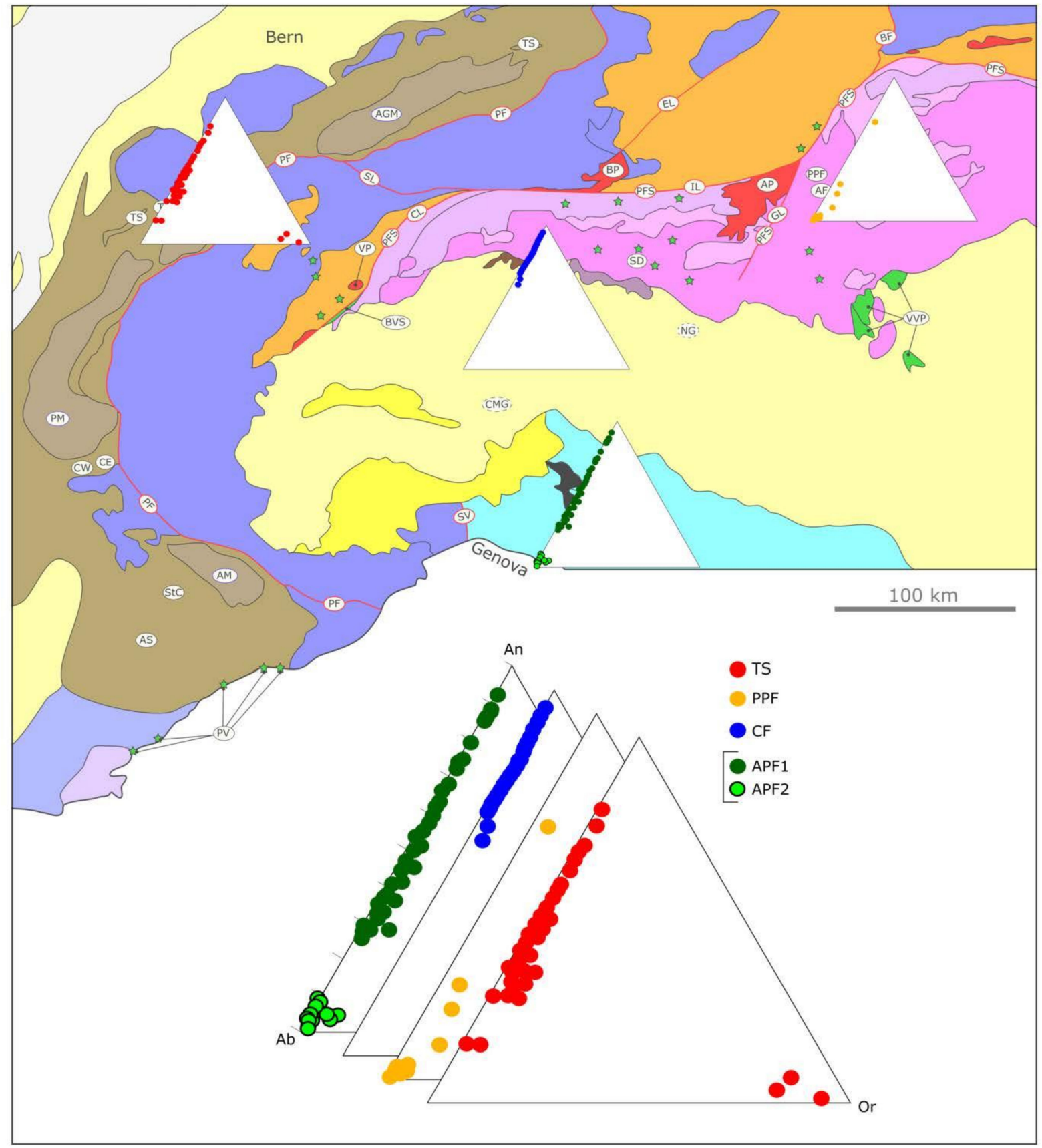

Figure 4. Compositions of feldspar crystals. TS = Taveyanne Sandstones [31]; PPF = Ponte Pià Formation [32]; CF = Cibrone Formation (this work); APF = Val d'Aveto-Petrignacola Formation (1) [36] and (2) (this work on pyroclastic density current deposit described by [61]).

\subsection{The Adriatic Foredeep}

Differently from the NAFB, the Adriatic Foredeep received very little pulses of clastic sediments supplied by the Alpine Belt during the Eocene and the beginning of the Oligocene (Rupelian) starved stage of [19]. Sedimentation was mainly represented by marls and shales, locally interrupted by calcareous deposits fed by thrust-top carbonate platforms delimiting the interconnections between proximal and distal environments (e.g., Ternate-Travedona Formation in the Brianza area [62]; Pradelgiglio Formation in the Giudicarie Belt [63]). Occasionally, the marly sedimentation shows intercalations of coarse deposits whose siliciclastic detritus has an Alpine provenance fingerprint (cfr Montorfano 
Lariano Member of the Tabiago Formation in the Brianza area [64]; Val d'Agola Formation in the Giudicarie belt [47]). Volcanogenic sedimentation, preponderant in the NAFB, is here restricted to scattered and spatially limited deposits included into the Cibrone Formation (Brianza Area), the Val D'Agola and Ponte Pià Formations (Giudicarie Belt), and the Borgosatollo 01 and Chiari 01 wells (Figures 1 and 2) [1,2,32,35,47,65].
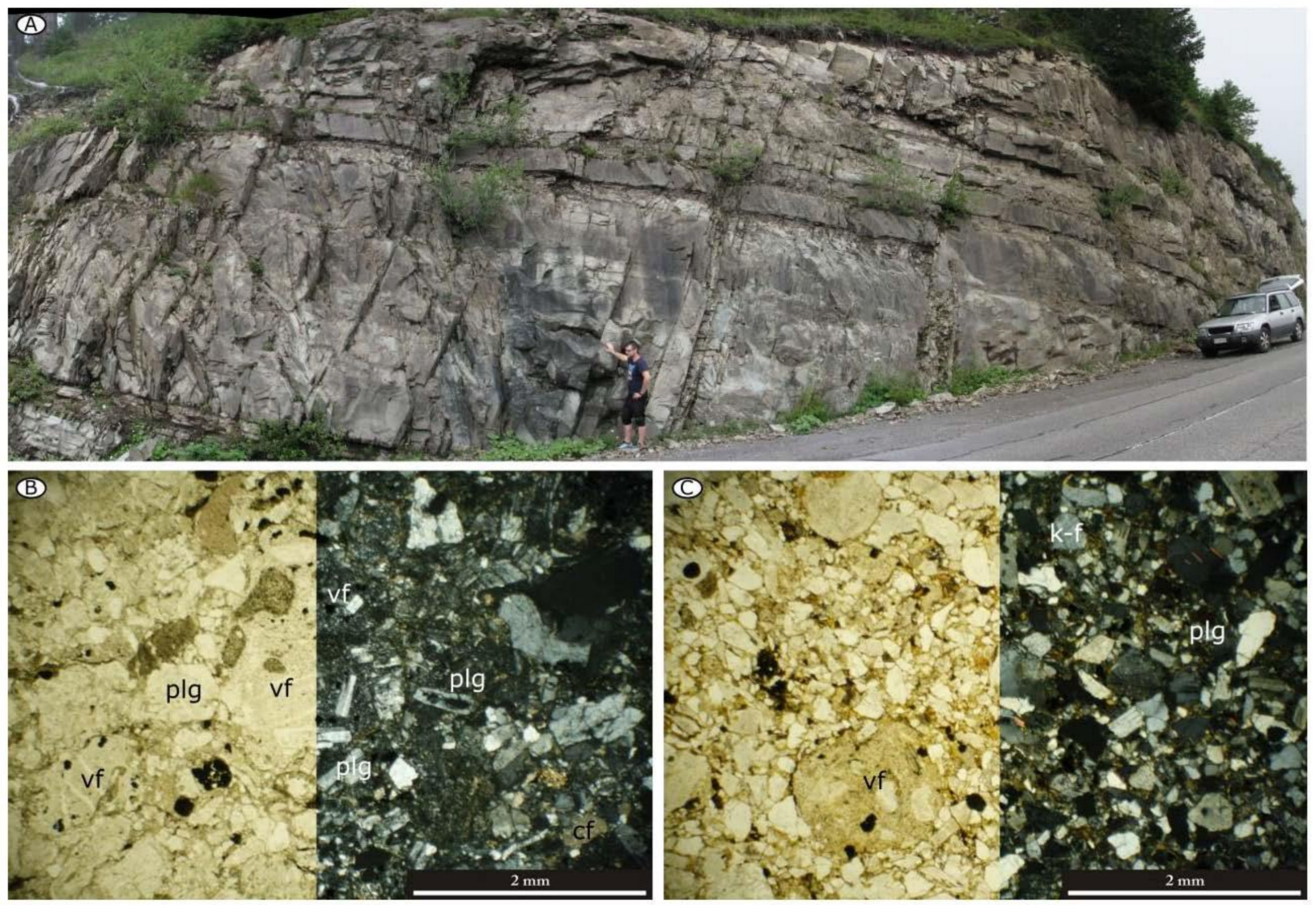

Figure 5. (A) A typical stratigraphic sequence of Taveyanne Sandstones in SE France, constituted of thick volcanogenic beds intercalated by thinner marly layers and nonvolcanic deposits. Dr. Crippa to scale. (B) Thin section of a syn-volcanic deposit, crossed nichols on the right. Large amounts of particles, plastically deformed, form a typical pseudomatrix and indicate short time between the production of detritus and its accumulation underwater. (C) Thin section of a postvolcanic deposit, crossed nichols on the right. The presence of rounded particles indicates that detritus underwent to erosion and transport before the underwater accumulation. All the photos are modified from [8]. Plg = plagioclase; $k-f=k-f e l d s p a r ;$ $\mathrm{vf}=$ volcanic rock fragment; $\mathrm{cf}=$ calcareous rock fragment.

The Cibrone Formation, accumulated on top of the Tabiago Formation in the Brianza area (Figures 1 and 2) is a marly sequence in which frequent fine sandstone turbidite layers are intercalated $[64,65]$ (Figure 6). Some of these turbidite layers are defined as plagioclase-arenite by $[66,67]$, because they are mainly constituted of fresh and euhedral single minerals of plagioclase, with subordinate volcanic rock fragments and single minerals of amphibole, biotite and opaques [67]. Among opaques, spinel minerals have mantle origins and were transported to the surface by syn-sedimentary mafic to intermediate volcanic rocks [65]. WDS geochemical data presented in this work agrees and expands the previous data of [67], showing that plagioclase minerals have a composition ranging from bytownite to labradorite (Figure 4). The other sandy layers are composed of limestone and dolomite lithics, monocrystalline quartz, polycrystalline quartz and minor cherts, phyllites, white micas and tourmaline. Paleocurrent measurements on volcanogenic sands indicate that detritus was sourced from ESE and NE [64]. On the basis of biostratigraphic data, the Cibrone Formation has been dated to the Middle Lutetian-Upper Bartonian 
(Eocene) [35], although fission track measurements on apatites performed by [68] indicate that the detritus has a Rupelian age (ca. $30 \mathrm{Ma}$ (Oligocene)). The latter authors also interpret these layers as distal dispersals of a hypothetic volcanic centre once located above the Bergell pluton.
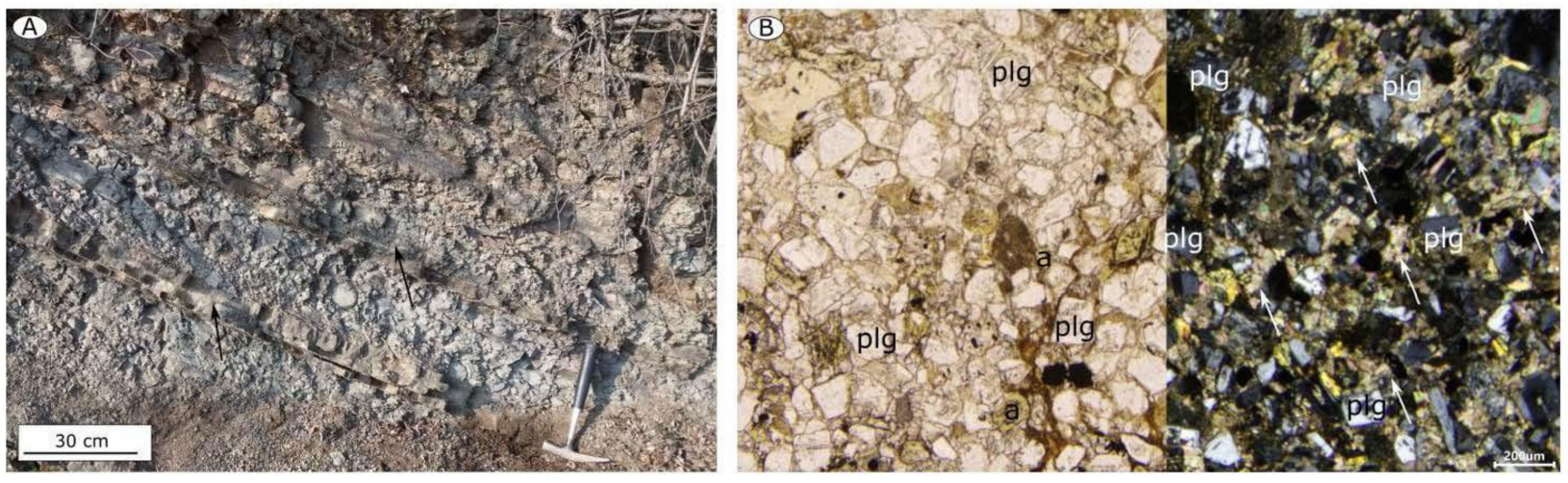

Figure 6. (A) Thin-layered volcanogenic sandstones (black arrows) in the marly sequence of the Cibrone Formation. (B) Thin section of a volcanogenic sandstone layer of the Cibrone Formation, crossed nichols to the right. Note the large amount of secondary calcite (white arrows) and zoned plagioclase minerals (plg). A = amphibole.

Few data are available on the volcanogenic detritus of the Borgosatollo 01 and Chiari 01 wells, described as basaltic tuffs Paleocene (?) to Eocene in age [1].

The Val d'Agola and Ponte Pià formations have a stratigraphic sequence similar to that of the Cibrone Formation, but the volcanogenic sandstone successions, comprised in the hemipelagic marly deposits, could reach $20 \mathrm{~m}$ in thickness [2,32] (Figures 1 and 2). Furthermore, the Val d'Agola Formation also includes conglomerates with andesite olistoliths and few volcanic layers defined as "lavas" by [2]. The volcanogenic deposits are turbidite and submarine mass-flow deposits, whose detritus is enriched in single minerals of plagioclase (up to $50 \%$ ), minor volcanic rock fragments (some of them produced by subaqueous eruptions), heavy minerals often cloritized (biotite, amphibole, opaques), and rare accidental quartz [2,32] (Figure 3). $\mathrm{U} / \mathrm{Pb}$ ages on detrital zircons of $[37,59]$ indicate a syn-sedimentary volcanic source providing detritus to the foredeep sequences. Geochemical analyses (Figure 4) reveal that the volcanic detritus has affinities with the Re di Castello pluton (part of the Adamello batholith) and associated dykes, with minor contributions from the VVP for the older terms $([2,37,59])$. In addition, [2] and more recently [59] indicate a Lower to Upper Eocene (48.2-33.1 Ma U/Pb on zircons) age for the volcanic detritus within these formations.

\subsection{The Northern Apennine Foredeep}

As in the Adriatic Foredeep, the Eocene sedimentary record of the Northern Apennine Foredeep basin was characterized by the accumulation of muddy, marly and calcareous sediments with rare sandy intercalations (e.g., Argille e Calcari di Canetolo, Flysch di Vico [60]). According to [69] (and ref. therein), in fact, most of the terrigenous supply coming from the Ligurian Alps and Corsica was trapped into the piggyback basins interposed between the Ligurian-Penninic orogenic wedge and the foredeep basin. In these basins, also rare volcaniclastic intercalations occur during the Middle Eocene (Montepiano Marls) and the Early Oligocene (Ranzano Formation) [67]. These volcaniclastic layers are constituted of fresh and euhedral single minerals of plagioclase, variable amounts of ferromagnesian minerals (biotite, amphibole and opaques), rare volcanic rock fragments and volcanic quartz [67].

In the foredeep basin, instead, the first massive clastic inputs began the accumulation during the Oligocene (ca. $32 \mathrm{Ma}$, Rupelian), and led to the progradation of the nonvolcanic turbidite system of the lower part of the APF $[34,36,60]$. The APF has a complex stratigraphy, and its products are not limited to siliciclastic deposits [60,70]. At the bottom, a thick 
sequence of calcareous turbidites interfingering with fine drapes of varicoloured claystones opens the sedimentary sequence. Above it, thick packages of sandstones and conglomerates are arranged in channel and overbank deposits [70]. These sediments are mainly composed of metamorphic (quartzites, ortogneiss, paragneiss, amphibolite micaschists and rare metagabbros), non-coeval magmatic (granite, pegmatite, dacite, slightly metamorphosed rhyolite and andesite) and minor sedimentary detritus (Figure 3) [36,60,70]. As indicated by [70], SardiniaCorsica block, SE France (Provence area) and Ligurian Alps are the most suitable areas from where the detritus came during the Oligocene. According detrital U/Pb zircon ages, [9] indicate that the Alps were the only source of the APF detritus. At around $31.09 \pm 0.30 \mathrm{Ma}$ $\left(\mathrm{U} / \mathrm{Pb}\right.$ on zircons [9]) until $29.2 \mathrm{Ma}\left({ }^{40} \mathrm{Ar} /{ }^{39} \mathrm{Ar}\right.$ age on a volcanic clast [49]), large volumes of volcanogenic detritus started to feed the turbidite system, overwhelming and/or mixing with the nonvolcanic supply [36,60]. Documented also by [61,70], for the first time, an almost $60 \mathrm{~m}$-thick sequence of channelized pyroclastic density current deposits (from a metre to several metres thick) overlain by a debris avalanche deposit (Figures 3, 4 and 7). In these deposits, rare accidental phengite-bearing schists have been documented by [70]. Field paleocurrent measurements [71-73] indicate that volcanogenic detritus moved from NW to SE. The origin of the volcanogenic sequences is still debated. Based on detrital zircon fingerprint, [9] indicate the Bergell pluton (central Alps) as the magmatic source of such sequences. Consequently, these authors sustain that the nonvolcanic detritus bearing $\mathrm{U} / \mathrm{Pb}$ zircons Cretaceous in age is derived from the Alpine terrains around the Bergell pluton. This would also be consistent, for the authors, with the NW trending paleocurrents measured by [71-73] that would point to NE if back-rotated according to the counterclockwise movements of the Apennines [74]. On the contrary, [70] indicate the syn-sedimentary volcanism of the Provençal margin as the most suitable magmatic source of them, based on the provenance of nonvolcanic detritus and palinspastic reconstruction and comparison. Only on the base of the geochemical characters of the volcanogenic detritus, [36] explain the particular geochemical signature of the APF as due to a local magmatic event, triggered by the break-off of the European slab during the switch of subduction polarity in the Oligocene.
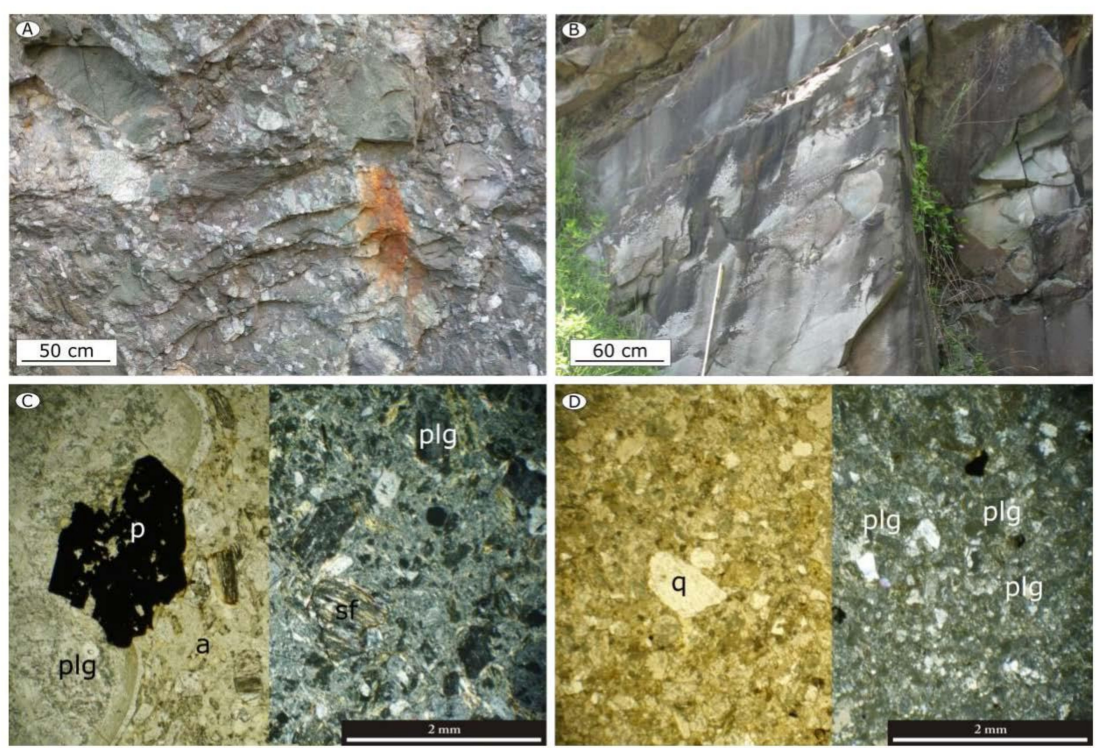

Figure 7. (A) Coarse-grained pyroclastic density current deposit of the Val d'Aveto FormationPetrignacola Formation. (B) Thick volcanogenic sandstones of the Val d'Aveto-Petrignacola Formation. (C) Thin section of a pyroclastic density current deposit of the Val d'Aveto-Petrignacola Formation, crossed nichols on the left. (D) Thin section of a volcanogenic sandstone of the Val d'Aveto-Petrignacola Formation, crossed nichols to the left. Large amounts of particles, plastically deformed, form a typical pseudomatrix and indicate short time between the production of detritus and its accumulation underwater. All the photos are modified from [70]. Plg = plagioclase; $\mathrm{p}=$ pyrite; $\mathrm{q}=$ quartz; $\mathrm{a}=$ amphibole; $\mathrm{sf}=$ phengite-bearing schist rock fragment. 
The uppermost part of the APF includes layers enriched in ophiolite-derived detritus and calcareous fragments ascribed to Liguridi and/or Subliguri Units [75], together with fine hybrid layers composed of calcareous and basement-derived detritus [70]. The incoming of ophiolite detritus has been correlated to the activation of the Sestri-Voltaggio fault system in the Voltri Group area [70].

\section{Reassessing the Source-to-Sink System: An Actualist View}

\subsection{The Northern Alpine Foreland Basin (NAFB)}

The depiction of a convincing snapshot of Alps and related depositional systems at the Eocene-Upper Oligocene boundary is tricky. Most of the volcanic sources and their primary connections with depocenters have been, in fact, completely disarticulated or deleted by the post-Rupelian evolution of the belt. Close to the thick outcropping volcanogenic successions, almost no volcanic features have been recognized. On the contrary, where volcanogenic detritus is restricted to thin and scattered layers, volcanic features are represented by small volcanic bodies and effusive products accumulated on top of the Mesozoic sequences or the Hercynian basement. These differences, inherited from the different tectonic evolution between the Northern and the Southern Alps across the PFS, pushed Alpine geologists to identify in the large Periadriatic plutons the deep roots of ancient volcanic edifices unroofed during the Chattian, which would have been the only sources of volcanogenic detritus for the entire foreland basins around the Alps [68]. This hypothesis has consequently influenced the reconstruction of the pathways that supplied the volcanogenic detritus to the NAFB, the Adriatic and the Northern Apennine foredeeps (e.g., $[6,9,76])$.

Although efficient to unravel the Alpine chain exhumation history, this oversimplification left along its path many clues fundamental in the reconstruction of volcanogenic aprons and their feeding systems. Combining stratigraphy with geochemical, petrographic and geochronological data, it is recognized that the first volcanogenic aprons and volcanic manifestations occurred in the Adriatic Foredeep. In the eastern part of the basin, volcanogenic aprons (Ponte Pià and Val d'Agola formations) were directly fed by the submarine eruptions of the VVP and eruptive centres related to the older suites of the Adamello [2,59] (Figure 8).

To the west, the volcanogenic detritus of the Cibrone Formation was accumulated in the central part of the Adriatic Foredeep (accounting the biostratigraphic age of [35]). The abrupt incoming of volcanogenic detritus in the basin represents, for the Cibrone Formation, a proof that volcanism and sedimentation were contemporaneous [77]. Therefore, these volcanogenic layers could be considered as crystal-rich tuffs, according to [66], and consequently interpreted as the product of pyroclastic density currents accumulated underwater [78] or their rework [79]. Although source is still uncertain, the occurrence of Cr-bearing spinels in the volcanogenic sediments, typical of basaltic to andesitic magmas from harzburgites of a Supra-Subduction Zone [65], might suggest that the volcanogenic detritus was originated by small eruptive centres on top of the subintrusive bodies described by [42] in the Southern Alps. These hypothetical eruptive centres were subsequently eroded, as such kind of volcanic morphologies are generally highly prone to erosion [80,81]). In addition, all the Cretaceous to Paleocene sequences actually interposed between the potential source area and the Cibrone depocenter have been structured, together with the same Cibrone Formation, only starting from $34 \mathrm{Ma}$ [13]. This would imply that the biostratigraphy ages of [35] correspond to the depositional age of the Cibrone Formation and give a temporal constraint to the volcanic source, which therefore was not the Bergell magmatic system, in disagreement with [68] (Figure 8). On the other hand, if the ages provided by [68] are the correct ones, the tectonic event involving the Cretaceous to Paleogene pile must be postdated, but provenance from the Bergell magmatic system remains difficult to explain according to the paleocurrent directions [64]. 
A - Ypresian ca. $49 \mathrm{Ma}$

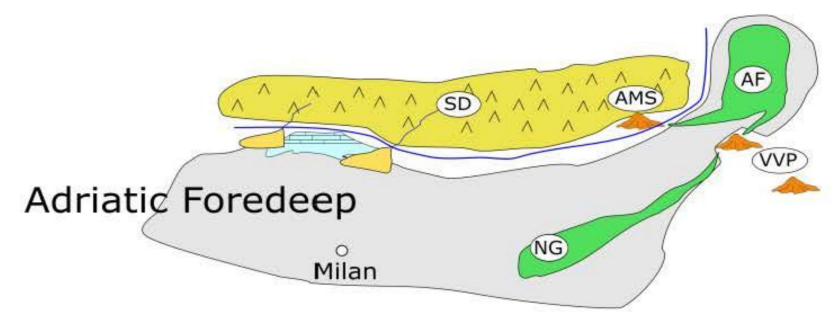

B - Bartonian ca. $40 \mathrm{Ma}$

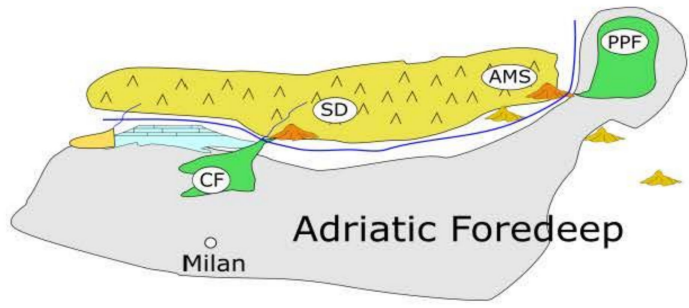

C - Priabonian/Rupelian ca.34 Ma

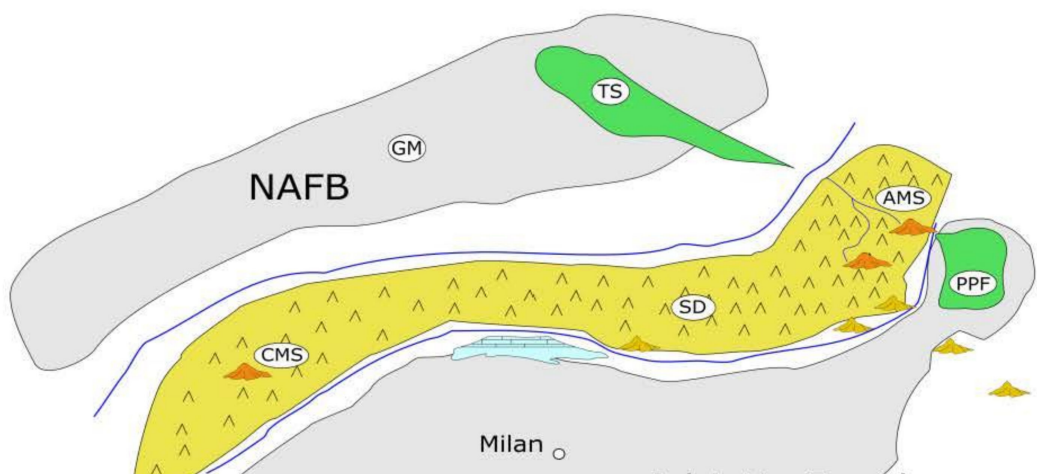

Milan o

Adriatic Foredeep
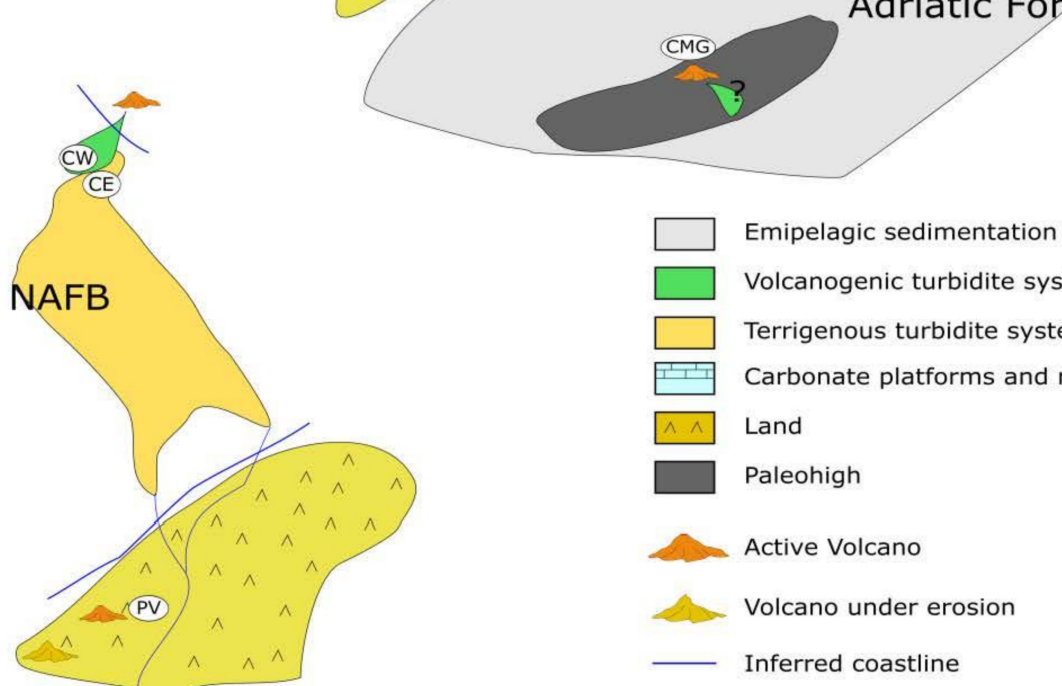

Volcanogenic turbidite system

Terrigenous turbidite system

Carbonate platforms and related aprons

Land

Paleohigh

Active Volcano

Volcano under erosion

Inferred coastline

Figure 8. Paleogeographic reconstruction of the source-to-sink systems around the Alps during the Ypresian (ca. $49 \mathrm{Ma}-\mathrm{SD}=$ southalpine dykes; AMS = Adamello Magmatic System; AF = Val d'Agola Formation; VVP = Venetian Volcanic Province; NG = Gallare Marls), during the Bartonian (ca. $40 \mathrm{Ma}, \mathrm{CF}=$ Cibrone Formation; PPF = Ponte Pià Formation), and during the boundary between Priabonian and Rupelian (ca. $34 \mathrm{Ma}, \mathrm{NAFB}=$ Northern Alpine Foreland Basin; TS = Taveyanne Sandstones; GM = Globigerina Marls; CMS = Biella Magmatic System; CMG = Cerano-Mortara-Garlasco volcano; CW = Western Champsaur; $\mathrm{CE}=$ Eastern Champsaur; $\mathrm{PV}=$ Provence Volcanoes). 


\subsection{NAFB and the Source-to-Sink System}

In the NAFB, volcanogenic sedimentation began later than in the Adriatic Foredeep, from $\sim 34 \mathrm{Ma}$, according to the biostratigraphic constraints of $[31,54,58]$ (Figure 8). Therefore, geochronological ages on the volcanogenic detritus reveal that only part of the detritus was coeval to sedimentation, whereas the other part derived from the accumulation after processes of weathering/erosion and transport of previous volcanic successions and related magmatic bodies. In the basin where the Taveyanne Sandstones (TS) (Figure 8) were accumulated, volcanic pebble ages support the hypothesis of a volcanic control on sedimentation. Magmatic zircon populations add spatial and temporal constraints on the volcanic source. All the zircon populations of [37] share the "34-32 Ma ages". In SE Switzerland, the progradation of volcanogenic successions was controlled by the volcanic centres located in the Northern Adamello area, together with those in the Bergell area from $33 \mathrm{Ma}$. The net distinction among sandstones with Adamello geochemical signature and Bergell geochemical signature [37] clearly indicates that in the basin two distinct turbidite systems were accumulating. The turbidite system supplied by the Adamello magmatic system (AMS) (Figure 8) received a mix of syn-volcanic and post-volcanic detritus (sensu [77]), as showed by zircon ages with AMS geochemical signature (from 41 to $32 \mathrm{Ma}$ [37]). Part of the volcanic detritus was generated and accumulated into the basin from active volcanic centres (syn-volcanic detritus), whilst part of the magmatic detritus was produced by the erosion of older volcanic centres and related intrusive bodies located in the southern part of the Adamello magmatic system (post-volcanic detritus). This latter hypothesis is supported by ages and geochemical signatures of the older (up to $41 \mathrm{Ma}$ ) magmatic zircons comparable to those of the magmatic zircons in the Val d'Agola Formation, according to $[37,59]$. Thus, the Adamello area in the Rupelian time was probably an emerged land with volcanic edifices that rejuvenate toward northeast, following the intrusions of magmatic bodies composing the Adamello batholith, such as the modern Kamchatka [82], the Central Andes [83] or the Trans-Mexican Volcanic Belt [84]. Volcanic activity favoured the accumulation of the Adamello magmatic detritus as long as explosive eruptions largely provided volcanogenic detritus to the drainage path [8] to the north in the NAFB, as well as to the eastern part of the Adriatic Foredeep basin (Val d'Agola Formation, up to $33 \mathrm{Ma}$ ). After $\sim 32 \mathrm{Ma}$, the Adamello volcanic system ceased its activity, and the related magmatic detritus became available only by weathering/erosion. The absence of any stratigraphic data correlated to the clusters of zircon populations does not give further information on how (and if) the Adamello magmatic system provided detritus after ceasing the volcanic activity.

The Bergell magmatic system provided detritus almost all during the accumulation of sediments into the Taveyanne basin (33-29 Ma [37]). Comparing these ages with those provided by [27] (and ref. therein), the only place where the magmatic detritus could have been originated until $29 \mathrm{Ma}$ is the Bergell tonalitic tail, i.e., the narrow tonalitic suite elongated from the top of the Lake Como to near Bellinzona, whereas all the other parts of the Bergell pluton ceased their activity at $~ 30 \mathrm{Ma}$. According to [85], this tail represents the deepest part of the pluton, so almost $13 \mathrm{~km}$ of crust have been deleted by the subsequent exhumation of the Lepontine dome surrounding it ([27] and ref. therein). In addition, the actual shape of the pluton does not reflect its shape during the correspondent volcanic activity, but is the result of a complex interaction between the magma intrusion and syn- to post-intrusive tectonics [85]. During its intrusion, magma raised up from South to North into the Pennine nappes above different units up to the Misox Zone (Adula Nappe) [85]. These data, together with those of $[16,86]$ (and ref. therein), document that the Lepontine Dome was exhumated not prior to the middle Miocene and that the various phases of thrust and nappe formation within the foreland basins were almost coeval with this exhumation, allowing speculation that the volcanic centres fed by the Bergell magmatic system were not restrained along the PFS, but were located close to the basin. In addition, the recovery of volcanic bombs within the volcanic detritus reported by [58] suggests that some of them could have been littoral. This speculation could be supported by the presence of few dykes crosscutting the Aar Massif and Eocene Nummulithic Limestones, as well as the large amount of old and nonvolcanic detritus and detrital zircons [37] 
ascribable to the plutono-metamorphic terrains of the Austroalpine domain not involved in the Alpine metamorphism. The subsequent exhumation of the Lepontine dome and the Aar-Gotthard Massif has completely disarticulated the magmatic system, giving the mendacious appearance of volcanic manifestations without relationships with magmatic systems (Figure 8).

In SE France, Taveyanne Sandstones were accumulated between 32 and 29 Ma [31] (Figure 9). The paleodrainage reconstruction proposed by [12] well fits with the literature data available on the Western Southern Alps. Volcanogenic detritus was produced by the Biella magmatic system, whereas the metamorphic detritus derived mainly from the Sesia Lanzo and Ivrea-Verbano zones and the sedimentary detritus was recycled from the Cretaceous to Late Paleogene clastic sequences, such as the Préalpes Médianes Flysch. The $\mathrm{U} / \mathrm{Pb}$ ages of its detrital magmatic zircons (34-31 Ma [37]) and those in the BVS (32.89-32.44 Ma [3]) give further information for thought about the location of the volcanic centres in the Biella area, although the Sesia Lanzo Zone tilting deleted the Oligocene paleogeography. The BSV ages were gained on pyroclastic deposits $[3,41]$ so on deposits that have travelled some kilometres (few tens?) from elsewhere before settling in the Biella area, implying that other centres, beyond those at Biella, were present on the Sesia Lanzo Block. Therefore, the older detritus could have been provided by volcanic centres probably located closer to the basin, maybe to the west of the BSV, where rotated Oligocene dykes are described by $[15,41]$. A closer position of the volcanic centres with respect to the shoreline would be also confirmed by the recognition of submarine deposits of subaerially generated pyroclastic density currents [8]. On the other side, the younger detritus could have been not provided by the BVS, as these volcanic centres were already buried due to the block tilting. The only putative location, where the volcanic source could have been shifted after $32 \mathrm{Ma}$, could be to NW, where not rotated Oligocene dykes crosscut the Sesia Lanzo Zone and the Piedmont-Ligurian Units [15] (Figure 8).

The paucity of data on the western Champsaur basin results in a low-constrained reconstruction of the potential volcanogenic source and how it interacted with the sedimentary system. A Bergell signature as proposed by [7] seems to be in contrast with the provenance signature of the Taveyanne Sandstones in the French area [37], unless considering a really complicated (and improbable) drainage system, as well as in consideration of the amounts of andesite cobbles documented in the Champsaur stratigraphic record [30]. A genetic correlation with the Flysch des Aiguilles volcanic layers described by some authors from the 1960s to the 1980 s seems to be the more probable $[87,88]$, but only a further and detailed work of comparison and stratigraphy could solve the problem. In the same way, a proximal but not defined provenance for the nonvolcanic detritus is discussed by [30]. The eastern Champsaur Basin, and the Annot and Saint Antonin basins were fed by the Maures-Esterel Massifs of SE France and the Corsica-Sardinia Block ([53] and ref. therein). In these basins, inputs of volcanogenic detritus (Saint Antonin Conglomerate) potentially derived from the Provence Tertiary Volcanism.

\subsection{The Northern Apennine Foredeep}

The recognition of the magmatic system sourcing the volcanogenic sequences of the APF is a fascinating problem that attracted many authors in the past decades $[9,36,49,70]$. The counterclockwise rotation of the Apennine belt consequently to the opening of the Tyrrhenian sea [74] further complicates this recognition. In addition, the different geodynamic reconstructions provided through the years further complicate the efforts in the repositioning of the sedimentary units where they were accumulated ([89] and ref. therein). Nevertheless, some constraints could be found matching the large amount of data available in literature (Figure 9). 


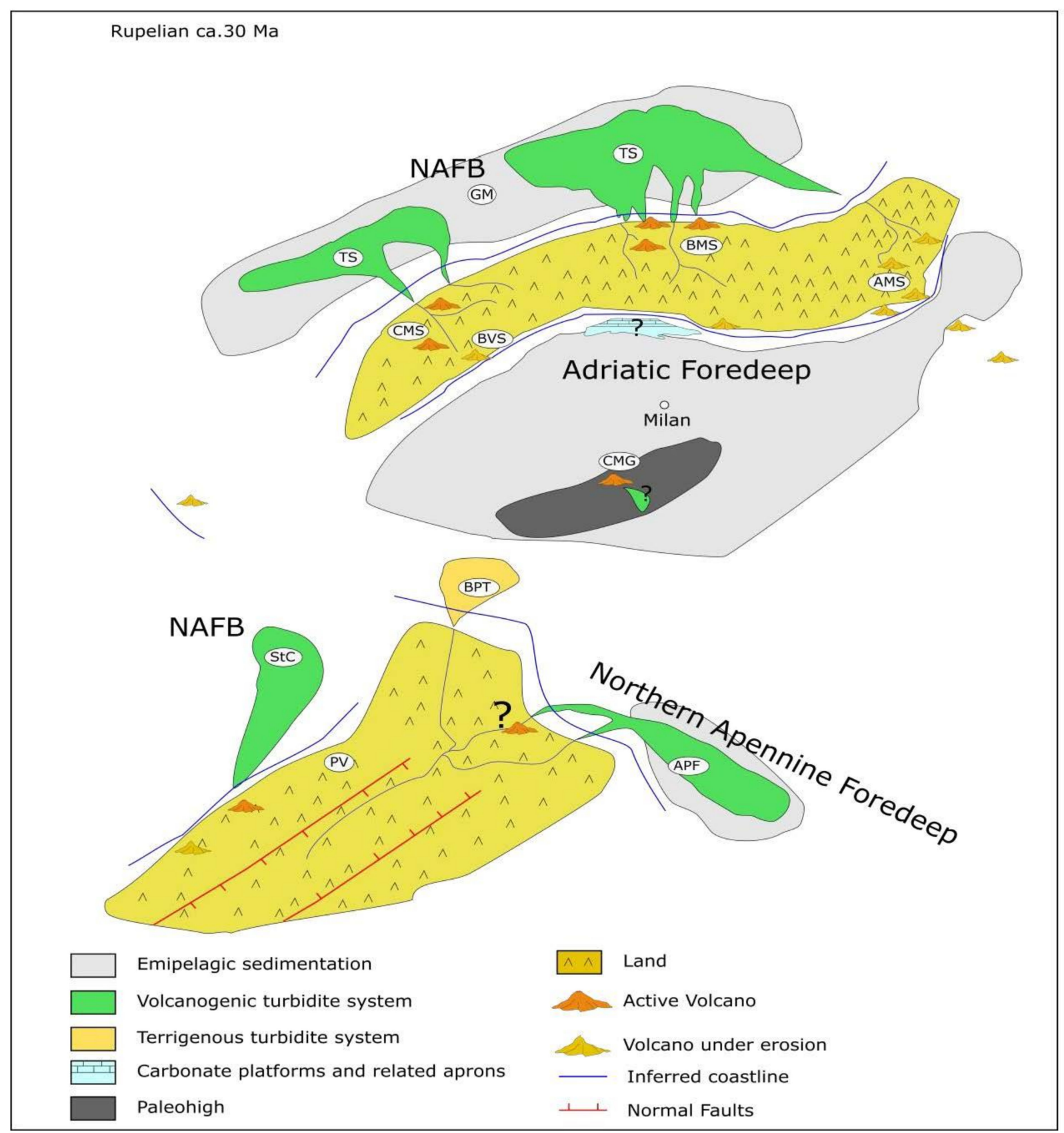

Figure 9. Paleogeographic reconstruction of the source-to-sink systems around the Alps during the Rupelian (ca. $30 \mathrm{Ma}$ ), NAFB = Northern Alpine Foreland Basin; AMS = Adamello Magmatic System; NG = Gallare Marls; TS = Taveyanne Sandstones; GM = Globigerina Marls; CMS = Biella Magmatic System; BVS = Biella Volcanic Suite; CMG = Cerano-MortaraGarlasco volcano; CW = Western Champsaur; CE = Eastern Champsaur; StC = Saint Antonin Conglomerate; BPT = Tertiary Piedmont Basin; APF = Val d'Aveto-Petrignacola Formation; PV = Provence Volcanoes. Question mark indicates a putative volcano isolated according to [36], but genetically related to the Provencal volcanism [70], feeding the APF.

Although fascinating, an Alpine provenance for the volcanogenic detritus in the APF [9] is very improbable because it is in contrast with many findings. First of all, the reconstruction does not consider that the Northern Apennine foredeep was not connected to the Adriatic foredeep during the Oligocene, as the Mesozoic geometries bordering the latter basin to the south acted as sedimentary barrier [90-92]. No funnels, as hypothesized by [9] (and ref. therein), have ever documented in the subsurface of the Po Plain, where the putative volcanogenic detritus should have passed through moving from the 
central Alps to the Northern Apennine Foredeep basin $[1,90,91]$. At the same time, no thick volcanogenic beds or siliciclastic beds (below the nonvolcanic clastic Gonfolite Lombarda Group-ca. 27.3 to ca. 13.5 Ma, according to [93]) have ever been encountered in seismic profiles and wells, except for the volcanogenic sequences of the CMG volcanic district, which is in turn interposed between the Adriatic and the Northern Apennine foredeeps on a paleohigh $[1,90,91]$. No volcanogenic detritus has ever been recovered intercalated in the calcareous detritus and calcareous sequences of the coeval carbonate platforms developed on the southern boundaries of the central Southern Alps [62], indicating the absence of a drainage pattern moving volcanogenic detritus from the central Alps to the Adriatic foredeep. Even forcing an Oligocene age for the Cibrone Formation, grain size and limited thickness of these volcanogenic beds are incompatible with the very coarse and very thick pyroclastic density current deposits exposed in the APF [8]. Furthermore, the latter could not have travelled for at least $300 \mathrm{~km}$ from the source for physical limits [94]. In addition, the high fertility of Oligocene magmatic zircons of most parts of APF [9] has no correspondence with the very low fertility of magmatic zircons documented in all the Taveyanne Sandstones [37]. NE-trending paleocurrents are a weak provenance constraint as foredeep basins turbidite currents generally flow aligned along the basin longest axes [95]. All these findings safely exclude the Bergell magmatic system from the potential sources of the APF volcanogenic detritus, in disagreement with [9], as well as for its southward prosecution in the Elba Island, also in disagreement with [76]. Therefore, the detritus of the APF must have been provided by terrains located to the SW of the basin (in the actual position) [70]. This provenance agrees with signatures of clastic detritus in the coeval basins developed in the Northern Apennines and to SE $[90,96-98]$ that underline the fundamental role of the Ligurian-Penninic orogenic wedge in the production of the Apennine Oligocene detritus, as well as the Sardina-Corsica block and the Ligurian Cretaceous sedimentary units already exposed in the Oligocene near those terrains (e.g., Antola Formation). A similar provenance also explains the presence of zircons with Cretaceous ages in the APF detritus [9], as the Ligurian-Penninic orogenic wedge shared the high-pressure low-temperature (HP-LT) metamorphic conditions with the Alps in the Cretaceous $[99,100]$. This interpretation is also supported by the Cretaceous zircon age peaks in the coeval volcanogenic Tufiti di Tusa Formation (Southern Apennines), which derived from other remnants of the Cretaceous Alpine wedge disarticulated during the Eo-Oligocene [101].

SE France area cannot be safely excluded from the source-to-sink system, as far as nobody has ever considered the real position of the APF in the Oligocene times. It is quite impossible, in fact, that the APF was accumulating to the east of Corsica, a fact that would imply a long-distance drainage pattern [9]. On the contrary, APF was probably located in front of the Ligurian-Penninic orogenic wedge, somewhere tens of $\mathrm{km}$ to the SW with respect to its actual position on the Adriatic plate [90], in between the northern Corsica and the Ligurian Alps. This palaeographic location implies that the APF was away from the northern volcanic sources (Alps and CMG) and near the Provençal volcanic arc remnants. According to [102], part of this volcanic arc grew onto the Ligurian-Penninic orogenic wedge, like the volcanic successions near Nice. The subsequent opening of the Ligurian-Provençal Basin completely deleted the original drainage of the area. Consequently, volcanic edifices were partially eroded and partially drowned into the basin [103]. In a similar context, the existence of a volcanic source completely disappeared after Rupelian, as hypothesized by [36], could be supported.

\section{Concluding Remarks}

The review presented here offers a first $4 \mathrm{D}$ model describing the evolution of the source-to-sink systems in relation to the evolution of the magmatic systems grown within the Alps across the Eo-Oligocene boundary. From the Eocene (Figure 8), the activation of the magmatic feeding systems in the Southern Alps, the southern Adamello and the VVP, favoured the accumulation of volcanogenic sequences in all the Adriatic Foredeep. Looking at the volcanic successions and volcanogenic deposits, it is possible to speculate that part of the volcanic activity was subaerial, supplied by littoral and/or island volcanoes, 
and part was submarine. In addition, it is possible to infer that volcanogenic successions now forming the Cibrone Formation were probably supplied from eruptive centres located in the central Southern Alps (east to the Cibrone Formation). Then, the progressive northward migration of the magmatic sources activated the accumulation of volcanogenic sequences in the Swiss NAFB. The acme of the volcanic activity occurred at $32 \mathrm{Ma}$, when a drainage pattern allowed the transport of the volcanogenic detritus of the Biella and Bergell plutons to the French NAFB, whereas the Provence volcanism, together with putative local sources near the Pelvoux Massif, fed the western part of the NAFB. During this period, volcanoes were on land, some near and some far away from the shoreline, as testified by the presence of pyroclastic density currents subaqueously emplaced [8]. At 30 Ma (Figure 9), volcanogenic detritus also reached the Northern Apennine Foredeep. The palinspastic reconstructions proposed by $[90,92]$ definitively exclude the Alps from the potential sources, demonstrating that no interconnections existed between the Adriatic Foredeep and the Northern Apennine Foredeep. The nonvolcanic detritus preserved in the APF points to a provenance from SW, supplied by the Ligurian-Penninic orogenic wedge. This would suggest that the SE France volcanism could be a good potential source for the volcanogenic material, but further work needs to confirm this hypothesis.

In conclusion, beyond the regional case here presented, this work highlights that solid stratigraphy of sedimentary basins is the first step and the fundamental basis to constrain other analyses (e.g., petrographic, geochronological and sedimentological data) and to reconstruct the evolution of source-to-sink systems.

Author Contributions: Conceptualization, A.D.C. and F.B.; data curation, A.D.C.; writing-original draft preparation, A.D.C., F.B., G.G.; writing-review and editing, A.D.C., F.B., G.G.; visualization, A.D.C. All authors have read and agreed to the published version of the manuscript.

Funding: This research received no external funding.

Institutional Review Board Statement: Not applicable.

Informed Consent Statement: Not applicable.

Data Availability Statement: Not applicable.

Acknowledgments: The authors acknowledge Andrea Risplendente (UniMi) for WDS analyses on the Cibrone Formation. Two anonymous reviewers are acknowledged for improving an early version of the manuscript with fruitful comments.

Conflicts of Interest: The authors declare no conflict of interest.

\section{References}

1. Fantoni, R.; Bersezio, R.; Forcella, F.; Gorla, L.; Mosconi, A.; Picotti, V. New dating of the Tertiary magmatic products of the central Southern Alps, bearings on the interpretation of the Alpine tectonic history. In Proceedings of the 3rd Workshop on Alpine Geological Studies, Biella-Oropa, Italy, 1-29 October 1997.

2. Martin, S.; Macera, P. Tertiary volcanism in the Italian Alps (Giudicarie fault zone, NE Italy): Insight for double alpine magmatic arc. Ital. J. Geosci. 2014, 133, 63-84. [CrossRef]

3. Kapferer, N.; Mercolli, I.; Berger, A.; Ovtcharova, M.; Fügenschuh, B. Dating emplacement and evolution of the orogenic magmatism in the internal Western Alps: 2. The Biella Volcanic Suite. Swiss J. Geosci. 2012, 105, 67-84. [CrossRef]

4. D'Adda, P.; Zanchi, A.; Bergomi, M.; Berra, F.; Malusà, M.G.; Tunesi, A.; Zanchetta, S. Polyphase thrusting and dyke emplacement in the central Southern Alps (Northern Italy). Int. J. Earth Sci. 2011, 100, 1095-1113. [CrossRef]

5. Stanley, D.J. The Saint-Antonin Conglomerate in the Maritime Alps: A Model for Coarse Sedimentation on a Submarine Slope. Smithson. Contrib. Mar. Sci. 1980, 5, 28. [CrossRef]

6. Ruffini, R.; Polino, R.; Callegari, E.; Hunziker, J.C.; Pfeifer, H.R. Volcanic clastic-rich turbidites of the Taveyanne sandstones from the Thônes syncline (Savoie, France): Records for a Tertiary postcollisional volcanism. Schweiz. Mineral. Petrogr. Mitt. 1997, 77, 161-174.

7. Boyet, M.; La Pierre, H.; Tardy, M.; Bosch, D.; Maury, R. Nature des sources des composants andésitiques des Grès du Champsaur et des Grès de Tayevannaz. Implications dans l'évolution des Alpes occidentales au Palèogéne. Bull. Soc. Géol. Fr. 2001, 172, 487-501. [CrossRef]

8. Di Capua, A.; Groppelli, G. Application of actualistic models to unravel primary volcanic control on sedimentation (Taveyanne Sandstones, Oligocene Northalpine Foreland Basin). Sediment. Geol. 2016, 336, 147-160. [CrossRef] 
9. Anfinson, O.A.; Malusà, M.G.; Ottria, G.; Davof, L.N.; Stockli, D.F. Tracking coarse-grained gravity flows by LASS-ICP-MS depth-profiling of detrital zircon (Aveto Formation, Adriatic foredeep, Italy). Mar. Pet. Geol. 2016, 1163-1176. [CrossRef]

10. Ogniben, L.; Parotto, M.; Praturlon, A. Structural Model of Italy-Maps and explanatory model. Quad. Ric. Sci. 1975, 90, 502.

11. Lustrino, M.; Fedele, L.; Agostini, S.; Di Vincenzo, G.; Morra, V. Eocene-Miocene igneous activity in Provence (SE France): 40Ar/39Ar data, geochemical-petrological constraints and geodynamic implications. Lithos 2017, 288-289, 72-90. [CrossRef]

12. Lu, G.; Fellin, M.G.; Winkler, W.; Rahn, M.; Guillong, M.; von Quadt, A.; Willet, S.D. Revealing exhumation of the central Alps during the Early Oligocene by detrital zircon $\mathrm{U}-\mathrm{Pb}$ age and fission-track double dating in the Taveyannaz Formation. Int. J. Earth Sci. 2020, 109, 2425-2446. [CrossRef]

13. Zanchetta, S.; Malusà, M.G.; Zanchi, A. Precollisional development and Cenozoic evolution of the Southalpine retrobelt (European Alps). Lithosphere 2015, 7, 662-681. [CrossRef]

14. Lanza, R. Palaeomagnetic data on the andesitic cover of the Sesia-Lanzo Zone. West. Alps Geol. Rundsch. 1978, 68, 83-92. [CrossRef]

15. Berger, A.; Mercolli, I.; Kapferer, N.; Fügenschuh, B. Single and double exhumation of fault blocks in the internal Sesia-Lanzo Zone and the Ivrea-Verbano Zone (Biella, Italy). Int. J. Earth Sci. 2012, 101, 1877-1894. [CrossRef]

16. Price, J.B.; Wernicke, B.P.; Cosca, M.A.; Farley, K.A. Thermochronometry Across the Austroalpine-Pennine Boundary, Central Alps, Switzerland: Orogen-Perpendicular Normal Fault Slip on a Major "Overthrust" and Its Implications for Orogenesis. Tectonics 2018, 37, 724-757. [CrossRef]

17. Rubatto, D.; Hermann, J.; Berger, A.; Engi, M. Protracted fluid-induced melting during Barrovian metamorphism in the Central Alps. Contrib. Mineral. Petrol. 2009, 158, 703-722. [CrossRef]

18. Ciancaleoni, L.; Marquer, D. Syn-extension leucogranite deformation during convergence in the Eastern Central Alps: Example of the Novate intrusion. Terra Nova 2006, 18, 170-180. [CrossRef]

19. Garzanti, E.; Malusà, M.G. The Oligocene Alps: Domal unroofing and drainage development during early orogenic growth. EPSL 2008, 268, 487-500. [CrossRef]

20. Von Blackenburg, F.; Davies, J.H. Slab breakoff: A model for syncollisional magmatism and tectonics in the Alps. Tectonics 1995, 14, 120-131. [CrossRef]

21. Rosenberg, C.L. Shear zones and magma ascent: A model based on a review of the Tertiary magmatism in the Alps. Tectonics 2004, 23, 1-25. [CrossRef]

22. Bergomi, M.A.; Zanchetta, S.; Tunesi, A. The Tertiary dike magmatism in the Southern Alps: Geochronological data and geodynamic significance. Int. J. Earth Sci. 2015, 104, 449-473. [CrossRef]

23. Ji, W.-Q.; Malusà, M.G.; Tiepolo, M.; Langone, A.; Zhao, L.; Wu, F.-Y. Synchronous Periadriatic magmatism in the Western and Central Alps in the absence of slab breakoff. Terra Nova 2019, 31, 120-128. [CrossRef]

24. Mayer, A.; Cortiana, G.; Dal Piaz, G.V.; Deloule, E.; De Pieri, R.; Jobstraibitzer, P. U-Pb single zircon ages of the Adamello batholith Southern Alps. Mem. Sci. Geol. Padova 2003, 55, 151-167.

25. Schaltegger, U.; Brack, P.; Ovtcharova, M.; Peytcheva, I.; Schoene, B.; Stracke, A.; Marocchi, M.; Bargossi, G.M. Zircon and titanite recording 15 million years of magma accretion crystallization and initial cooling in a composite pluton (southern Adamello batholith northern Italy). Earth Planet Sci. Lett. 2009, 286, 208-218. [CrossRef]

26. Tiepolo, M.; Tribuzio, R.; Ji, W.Q.; Wu, F.Y.; Lustrino, M. Alpine Tethys closure as revealed by amphibole-rich mafic and ultramafic rocks from the Adamello and the Bergell intrusions (Central Alps). J. Geol. Soc. 2014, 171, 793-799. [CrossRef]

27. Gianola, O.; Schimdt, M.W.; von Quadt, A.; Peytcheva, I.; Luraschi, P.; Reusser, P. Continuity in geochemistry and time of the Tertiary Bergell intrusion (Central Alps). Swiss J. Geosci. 2014, 107, 197-222. [CrossRef]

28. Ji, W.Q.; Wu, F.Y.; Tiepolo, M.; Langone, A.; Abraga, B. Zircon U-Pb age and Hf isotope constraints on the petrogenesis of the Alpine Peri-Adriatic intrusions. Mineral. Mag. 2013, 77, 1386.

29. Schoene, B.; Schaltegger, U.; Brack, P.; Latkoczy, C.; Stracke, A.; Günther, D. Rates of magma differentiation and emplacement in a ballooning pluton recorded by U-Pb TIMS-TEA, Adamello batholith, Italy. Earth Planet. Sci. Lett. 2012, 355-356, 162-173. [CrossRef]

30. Waibel, A.F. Sedimentology, Petrographic Variability, and Very-Low-Grade Metamorphism of the Champsaur Sandstones (Paleogene, Hautes-Alpes, France): Evolution of Volcaniclastic Foreland Turbidites in the External Western Alps. Ph.D. Thesis, University of Geneva, Geneva, Switzerland, 1989.

31. Ruffini, R.; Cosca, M.A.; d'Atri, A.; Hunziker, J.C.; Polino, R. The volcanic supply of the Tertiary turbidites (Savoie, France): A riddle for Tertiary Alpine volcanism. Atti Del Convegno Rapp. Alpi Appennini 1994, 14, 359-376.

32. Sciunnach, D.; Borsato, A. Plagioclase-arenites in the Molveno Lake area (Trento): Record of an Eocene volcanic arc. Acta Geol. 1994, 69, 81-92.

33. Montenat, C.; Leyrit, H.; Gillot, P.-Y.; Janin, M.-C.; Barrier, P. Extension du volcanisme oligocène dans l'arc de Castellane (chaînes subalpines de Haute-Provence). Géol. Fr. 1999, 1, 43-48.

34. Catanzariti, R.; Cerrina Feroni, A.; Ottria, G.; Levi, N. The Contribution of Calcareous Nannofossil Biostratigraphy in Solving Geological Problems: The Example of the Oligocene-Miocene Foredeep of the Northern Apennines (Italy). In Geologic Problem Solving with Microfossils: A Volume in Honor of Garry D. Jones 93; Demchuck, T.D., Gary, A.C., Eds.; SEPM Special Publication: Broken Arrow, OK, USA, 2009; pp. 309-321.

35. Premoli Silva, I.; Tremolada, F.; Sciunnach, D.; Scardia, G. Aggiornamenti biocronologici e nuove interpretazioni ambientali sul Paleocene-Eocene della Brianza (Lombardia). Rend. Ist. Lomb. 2009. Available online: https://www.earth-prints.org/handle/21 22/5386 (accessed on 3 January 2021). 
36. Mattioli, M.; Lustrino, M.; Ronca, S.; Bianchini, G. Alpine subduction imprint in Apennine volcaniclastic rocks. Geochemicalpetrographic constraints and geodynamic implications from Early Oligocene Aveto-Petrignacola Formation (N Italy). Lithos 2012, 134-135, 201-220. [CrossRef]

37. Lu, G.; Winkler, W.; Rahn, M.; von Quadt, A.; Willett, S.D. Evaluating igneous sources of the Taveyannaz Formation in the Central Alps by detrital zircon U-Pb age dating and geochemistry. Swiss J. Geosci. 2018, 111, 399-416. [CrossRef]

38. Beccaluva, L.; Bigioggero, B.; Chiesa, S.; Colombo, A.; Fanti, G.; Gatto, G.O.; Gregnanin, A.; Montrasio, A.; Piccirillo, E.M.; Tunesi, A. Post collisional orogenic dyke magmatism in the Alps. Mem. Soc. Geol. Ital. 1983, 26, 341-359.

39. Alagna, K.E.; Peccerillo, A.; Martin, S.; Donati, C. Tertiary to Present Evolution of Orogenic Magmatism in Italy. J. Virtual Explor. 2010, 36, 1-63. [CrossRef]

40. Kapferer, N.; Mercolli, I.; Berger, A. The composition and evolution of an Oligocene regolith on top of the Sesia-Lanzo Zone (Western Alps). Int. J. Earth Sci. 2011, 100, 1115-1127. [CrossRef]

41. Callegari, E.; Cigolini, C.; Medeot, O.; D’Antonio, M. Petrogenesis of calc-alkaline and shoshonitic post-collisional Oligocene volcanics of the Cover Series of the Sesia Zone, Western Italian Alps. Geodin. Acta 2004, 17, 1-29. [CrossRef]

42. Bersezio, R.; Bini, A.; Ferliga, C.; Gelati, R. Note Illustrative della Carta Geologica d'Italia alla scala 1:50000, Foglio Bergamo. ISPRA 2012. Available online: https://www.isprambiente.gov.it/Media/carg/98_BERGAMO/Foglio.html (accessed on 3 January 2021).

43. Zanchi, A.; Chiesa, S.; Gillot, P.Y. Tectonic evolution of the Southern Alps in the Orobic chain: Structural and geochronological indications of pre-Tertiary compressive tectonics. Mem. Soc. Geol. Ital. 1990, 45, 77-82.

44. Furrer, H.; Hügi, T. Telemagmatischer Gang im Nummulitenkalk bei Trubeln westlich Leukerbad (Kanton Wallis). Eclogae Geol. Helv. 1952, 45, 41-51.

45. Pfiffner, A.Q. Geology of the Alps; West 894 Sussex; Wiley: Hoboken, NJ, USA, 2014; pp. 140-165.

46. Bellieni, G.; Fioretti, A.M.; Marzoli, A.; Visonà, D. Permo-Paleogene magmatism in the eastern Alps. Rend. Fis. Acc. Lincei 2010, 21, 51-71. [CrossRef]

47. Castellarin, A.; Picotti, V.; Cantelli, L.; Claps, M.; Trombetta, L.; Selli, L.; Carton, A.; Borsato, A.; Daminato, F.; Nardin, M.; et al. Carta Geologica D'ltalia, 1:50 000, F. 080 Riva Del Garda, Con Note Illustrative; APAT: Roma, Italy, 2005; p. 145.

48. Cassano, E.; Anelli, L.; Fichera, R.; Cappelli, V. Pianura Padana, interpretazione integrata di dati geofisici e geologici. $73^{\circ}$ Congr. Soc. Geol. Ital. 1986, 29, 22.

49. Mattioli, M.; Di Battistini, G.; Zanzucchi, G. Geochemical features of the Tertiary buried Mortara volcanic body (Northern Apennines, Italy). Boll. Soc. Geol. Ital. 2002, 1, 239-249.

50. Sinclair, H.D. Turbidite sedimentation during Alpine thrusting: The Taveyannaz sandstones of eastern Switzerland. Sedimentology 1992, 39, 837-856. [CrossRef]

51. Joseph, P.; Lomas, S.A. Deep-Water Sedimentation in the Alpine Foreland Basin of SE France: New Perspectives on the Grès d'Annot and Related Systems-An Introduction. In Geological Society; Special Publications: London, UK, 2004 ; p. 221.

52. Salles, L.; Ford, M.; Joseph, P. Characteristics of axially-sourced turbidite sedimentation on an active wedge-top basin (Annot Sandstone, SE France). Mar. Pet. Geol. 2014, 56, 305-323. [CrossRef]

53. Vinnels, J.S.; Butler, R.W.H.; McCaffrey, W.D.; Lickorish, W.E. Sediment Distribution and Architecture Around A Bathymetrically Complex Basin: An Example from The Eastern Champsaur Basin, SE France. J. Sediment. Res. 2010, 80, 216-235. [CrossRef]

54. Bodelle, J. Les Formations Nummulitiques de I'Arc de Castellane. Ph.D. Thesis, Universite de Nice, Nice, France, $1971 ;$ p. 582.

55. Baubron, J.C.; Cavelier, C. Numerical Dating in Stratigraphy; John Wiley \& Sons: Hoboken, NJ, USA, 1982.

56. Féraud, G.; Ruffet, G.; Stéphan, J.F.; Lapierre, H.; Delgado, E.; Popoff, M. Nouvelles données géochronologiques sur le volcanisme paléogène des Alpes occidentales: Existence d'un événement magmatique bref généralisé. Séanc. Spéc. Soc. Géol. Fr. 1996, $38,25-26$.

57. Debelmas, J.; Durozoy, G.; Kerckhove, C.; Monjuvent, G.; Mouterde, R.; Pècher, A. Carte Géologique de la France (1:50,000), Feuille Orcières (846); Bureau de Recherches Gèologiques et Minières: Orleans, France, 1980.

58. Lateltin, O. Les Dépôts Turbiditiques Oligocènes D'avant-Pays Entre Annecy (Haute-Savoie) et le Sanetsch (Suisse). Ph.D. Thesis, Fribourg University, Fribourg, Switzerland, 1988; p. 127.

59. Lu, G.; Di Capua, A.; Winkler, W.; Rahn, M.; Guillong, M.; von Quadt, A.; Willet, S.D. Restoring the source-to-sink relationships in the Paleogene foreland basins in the Central and Southern Alps (Switzerland, Italy, France): A detrital zircon study approach. Int. J. Earth Sci. 2019, 108, 1817-1834. [CrossRef]

60. Elter, P.; Catanzariti, R.; Ghiselli, F.; Marroni, M.; Molli, G.; Ottria, G.; Pandolfi, L. L'Unità Aveto (Appennino Settentrionale): Caratteristiche litostratigrafiche, biografia, petrografia, delle areniti ed assetto strutturale. Boll. Della Soc. Geol. Ital. 1999, 118, 41-63.

61. Di Capua, A.; Groppelli, G. Emplacement of pyroclastic density currents (PDCs) in a deep-sea environment: The Val d'Aveto Formation case (Northern Apennines, Italy). J. Volcanol. Geotherm. Res. 2016, 328, 1-8. [CrossRef]

62. Coletti, G.; Vezzoli, G.; Di Capua, A.; Basso, D. Reconstruction of a lost carbonate factory based on its biogenic detritus (Ternate-Travedona Formation and Gonfolite Lombarda Group-Northern Italy). Riv. Ital. Paleontol. Stratigr. 2016, $122,1-22$.

63. Barbieri, G.; Grandesso, P. Note illustrative della Carta Geologica d'Italia alla scala 1:50000. Foglio Asiago. ISPRA 2007. Available online: https:/ /www.isprambiente.gov.it/Media/carg/veneto.html (accessed on 3 January 2021). 
64. Bini, A.; Sciunnach, D.; Bersezio, R.; Scardia, G.; Tomasi, F. Note illustrative della Carta Geologica d'Italia alla scala 1:50000. Foglio Seregno. ISPRA 2015. Available online: https://www.isprambiente.gov.it/Media/carg/96_SEREGNO/Foglio.html (accessed on 3 January 2021).

65. Sciunnach, D. Geochemistry of Detrital Chromian Spinel as a Marker for Cenozoic Multistage Tectonic Evolution of the Alps. Rend. Online Soc. Geol. Ital. 2014, 32, 15-23. [CrossRef]

66. Gavazzi, A.; Miletta, S.; Sciunnach, D.; Tremolada, F. Eocene plagioclase-arenites from the Southern Alps: Record of a "meso-Alpine" volcanic arc. Ann. Uniservitatis Sci. Bp. Sect. Geol. 2003, 35, 102-103.

67. Di Giulio, A.; Dunkl, I.; Falletti, P.; Sciunnach, D. Plagioclas-arenites from the Northern Apennines and Southern Alps: Record of a Paleogene island arc related to Alpine subduction. In Proceedings of the 7th Alpine Workshop, Opatija, Croatia, 29 September1 October 2005.

68. Malusà, M.G.; Villa, I.M.; Vezzoli, G.; Garzanti, E. Detrital geochronology of unroofing magmatic complexes and the slow erosion of Oligocene volcanoes in the Alps. EPSL 2011. [CrossRef]

69. Cibin, U.; Di Giulio, A.; Martelli, L. Oligocene-Early Miocene Tectonic Evolution of the Northern Apennines (Northwestern Italy) Traced Through Provenance of Piggy-Back Basin Fill Successions. In Tracing Tectonic DeJormation Using the Sedimentary Record; Mccann, T., Saintot, A., Eds.; Geological Society; Special Publications: London, UK, 2003; Volume 208, pp. $269-287$.

70. Di Capua, A.; Vezzoli, G.; Groppelli, G. Climatic, tectonic and volcanic controls of sediment supply to an Oligocene Foredeep basin: The Val d'Aveto Formation (Northern Italian Apennines). Sediment. Geol. 2016, 332, 68-84. [CrossRef]

71. Mutti, E. Confronto tra le direzioni d'apporto dei clastici entro il Macigno e il “Tongriano" dell'Appennino di Piacenza. Riv. Ital. Paleontol. 1963, 69, 235-258.

72. Aiello, E. Le arenarie dell'Aveto, di Petrignacola e di M. Senario (Appennino settentrionale); osservazioni sedimentologiche e petrografiche. Boll. Della Soc. Geol. Ital. 1975, 94, 797-825.

73. Faini, P.; Forlani, A.; Vercesi, P.L. Caratteristiche sedimentologiche e strutturali delle Arenarie dell'Aveto. Atti Ticinensi Sci. Della Terra 1993, 36, 75-88.

74. Gattacceca, J.; Deino, A.; Rizzo, R.; Jones, D.S.; Henry, B.; Beaudoin, B.; Vadeboin, F. Miocene rotation of Sardinia: New Paleomagnetic and geochronological constraints and geodynamic implications. Earth Planet. Sci. Lett. 2007, 258, 359-377. [CrossRef]

75. Marroni, M.; Ottria, G.; Pandolfi, L. Note Illustrative della Carta Geologica d'Italia alla Scala 1:50000. Foglio Cabella Ligure. ISPRA 2010. Available online: https:/ / www.isprambiente.gov.it/Media/carg/196_CABELLA_LIGURE/Foglio.html (accessed on 3 January 2021).

76. Jacobs, J.; Paoli, G.; Rocchi, S.; Ksienzyk, A.K.; Sirevaag, H.; Elburg, M.A. Alps to Apennines zircon roller coaster along the Adria microplate margin. Sci. Rep. 2018, 8, 2704. [CrossRef]

77. Di Capua, A.; Groppelli, G. The riddle of volcaniclastic sedimentation in ancient deep-water basins: A discussion. Sediment. Geol. 2018, 378, 52-60. [CrossRef]

78. Trofimovs, J.; Sparks, S.J.R.; Talling, P.J. Anatomy of a submarine pyroclastic flow and associated turbidity current: July 2003 dome collapse, Soufrière Hills volcano, Montserrat, West Indies. Sedimentology 2008, 55, 617-634. [CrossRef]

79. Lube, G.; Cronin, S.J.; Manville, V.; Procter, J.N.; Cole, S.E.; Freundt, A. Energy growth in laharic mass flows. Geology 2012, 40, 475-478. [CrossRef]

80. Nemeth, K.; Kereszturi, G. Monogenic volcanism: Personal views and discussion. Int. J. Earth Sci. 2015, 104, 2131-2146. [CrossRef]

81. Nemeth, K.; Smith, I.E.M. Source to Surface Model of Monogenic Volcanism: A critical Review. In Monogenetic Volcanism; Geological Society; Nemeth, K., Carrasco-Nunez, G., Aranda-Gomez, J.J., Smith, I.E.M., Eds.; Special Publications: London, UK, 2017; p. 446.

82. Volynets, A.O.; Churikova, T.G.; Wörner, G.; Gordeychik, B.N.; Layer, P. Mafic Late Miocene-Quaternary volcanic rocks in the Kamchatka back arc region: Implications for subduction geometry and slab history at the Pacific-Aleutian junction. Contrib. Mineral. Petrol. 2010, 159, 659-687. [CrossRef]

83. Folguera, A.; Narajo, J.A.; Orihashi, Y.; Sumino, H.; Nagao, K.; Polanco, E.; Ramos, V.A. Retroarc volcanism in the northern San Rafael Block $\left(34^{\circ}-35^{\circ} 30^{\prime}\right.$ S), southern Central Andes: Occurrence, age, and tectonic setting. J. Volcanol. Geotherm. Res. 2009, 186, 169-185. [CrossRef]

84. Ferrari, L.; Conticelli, S.; Vaggelli, G.; Petrone, C.M.; Manetti, P. Late Miocene volcanism and intra-arc tectonics during the early development of the Trans-Mexican Volcanic Belt. Tectonophysics 2000, 318, 161-185. [CrossRef]

85. Davidson, C.; Rosenberg, C.L.; Schmid, S.M. Synmagmatic folding of the base of the Bergell pluton, Central Alps. Tectonophysics 1996, 265, 213-238. [CrossRef]

86. Steck, A. Tectonics of the Simplon massif and Lepontine gneiss dome: Deformation structures due to collision between the underthrusting European plate and the Adriatic indenter. Swiss J. Geosci. 2008, 101, 515-546. [CrossRef]

87. Martini, J.; Vuagnat, M. Essai de distinction mineralogique entre les termes fins du flysch helvetique. Arch. Sci. 1964, 18, 114-120.

88. Vuagnat, M. Les gres de Taveyanne et roches similaires: Vestiges d'une activite magmatique tardi-alpine. Mem. Soc. Geol. Ital. $1985,26,39-53$.

89. Molli, G. Northern Apennine-Corsica Orogenic System: An Updated Overview. In Tectonic Aspects of the Alpine-DinarideCarpathian System; Geological Society; Siegesmund, S., Fügenschuh, B., Froitzheim, N., Eds.; Special Publications: London, UK, 2008; Volume 298, pp. 413-442. 
90. Rossi, M.; Mosca, P.; Polino, R.; Rogledi, S.; Biffi, U. New outcrop and subsurface data in the Tertiary Piedmont Basin (NW-Italy): Unconformity-bounded stratigraphic units and their relationships with basin-modification phases. Riv. Ital. Paleontol. Stratigr. 2009, 115, 305-335.

91. Mosca, P.; Polino, R.; Rogledi, S.; Rossi, M. New data for the kinematic interpretation of the Alps-Apennines junction (Northwestern Italy). Int. J. Earth Sci. 2010, 99, 833-849. [CrossRef]

92. Turrini, C.; Toscani, G.; Lacombe, O.; Roure, F. Influence of structural inheritance on foreland-foredeep system evolution: An example from the Po valley region (northern Italy). Mar. Pet. Geol. 2016, 77, 376-398. [CrossRef]

93. Tremolada, F.; Guasti, E.; Scardia, G.; Carcano, C.; Rogledi, S.; Sciunnach, D. Reassessing the biostratigraphy and the paleobathymetry of the Gonfolite Lombarda Group in the Como area (Northern Italy). Riv. Ital. Paleontol. Stratigr. 2010, 116, 35-49.

94. Giordano, G.; Doronzo, D.M. Sedimentation and mobility of PDCs: A reappraisal of ignimbrites' aspect ratio. Sci. Rep. 2017, 7, 4444. [CrossRef] [PubMed]

95. Einsele, G. Sedimentary Basins: Evolution, Facies, and Sediment Budgets; Springer: Berlin/Heidelberg, Germany, $1991 ;$ p. 628.

96. Gianmarino, S.; Messiga, B. Clastidi Meta-ofioliti a paragenesi di alta pressione nel Conglomerato di Portofino: Implicazioni paleogeografiche e strutturali. Ofioliti 1979, 4, 25-41.

97. Cornamusini, G.; Pascucci, V. Sedimentation in the Northern Apennines-Corsica tectonic knot (Northern Tyrrhenian Sea, Central Mediterranean): Offshore drilling data from the Elba-Pianosa Ridge. Int. J. Earth Sci. 2014, 103, 821-842. [CrossRef]

98. Critelli, S. Provenance of Mesozoic to Cenozoic circum-Mediterranean sandstones in relation to tectonic setting. Earth-Sci. Rev. 2018, 185, 624-648. [CrossRef]

99. Gibbons, W.; Horak, J. Alpine metamorphism of Hercynian hornblende granodiorite beneath the blueschist facies schistes lustres nappe of NE Corsica. J. Metamorph. Geol. 1984, 2, 95-113. [CrossRef]

100. Gueydan, F.; Brun, J.-P.; Phillipon, M.; Noury, M. Sequential extension as a record of Corsica Rotation during Apennines slab roll-back. Tectonophysics 2017, 710-711, 149-161. [CrossRef]

101. Fornelli, A.; Gallicchio, S.; Micheletti, F.; Langone, A. Preliminary U-Pb Detrital Zircon Ages from Tufiti di Tusa Formation (Lucanian Apennines, Southern Italy): Evidence of Rupelian Volcaniclastic Supply. Minerals 2020, 10, 786. [CrossRef]

102. Peccerillo, A. Southern Tyrrhenian Sea. In Cenozoic Volcanism in the Tyrrhenian Sea Region; Peccerillo, A., Ed.; Springer: Berlin/Heidelberg, Germany, 2019.

103. Rolland, Y.; Lardeaux, J.-M.; Jolivet, L. Deciphering orogenic evolution. J. Geodyn. 2012, 56-57, 1-6. [CrossRef] 